(11) Nordiska ministerrådet

Nordiska ministerrådets samlade verksamhet

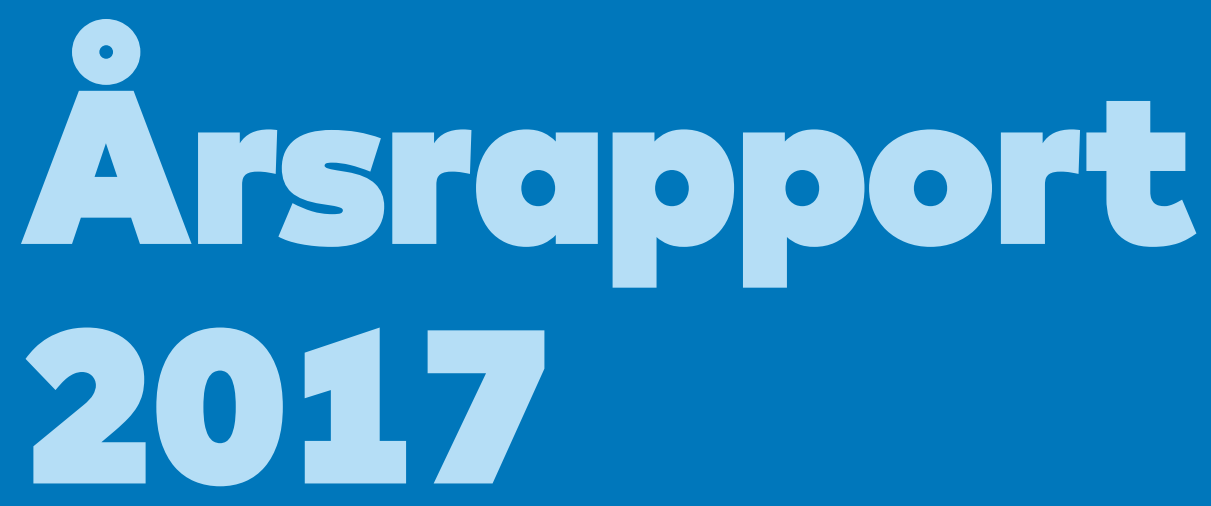




\section{Nordiska ministerrådets samlade verksamhet}

Årsrapport 2017 
Nordiska ministerrådets samlade verksamhet

Årsrapport 2017

\section{ANP 2018:801}

ISBN 978-92-893-5733-3 (PRINT)

ISBN 978-92-893-5734-0 (PDF)

ISBN 978-92-893-5735-7 (EPUB)

http://dx.doi.org/10.6027/ANP2018-801

(c) Nordiska ministerrådet 2018

Layout: Hanne Lebech

Det nordiska samarbetet

Det nordiska samarbetet är ett av världens mest omfattande regionala samarbeten. Det omfattar Danmark, Finland, Island, Norge och Sverige samt Färöarna, Grönland och Åland.

Det nordiska samarbetet är politiskt, ekonomiskt och kulturellt förankrat och en viktig del av europeiskt och internationellt samarbete. Den nordiska gemenskapen arbetar för ett starkt Norden i ett starkt Europa.

Det nordiska samarbetet vill styrka nordiska och regionala intressen och värderingar i en global omvärld. Gemensamma värderingar länderna emellan bidrar till att stärka Nordens ställning som en av världens mest innovativa och konkurrenskraftiga regioner.

Nordiska ministerrådet

Nordens Hus

Ved Stranden 18

1061 København K

www.norden.org

Ladda ner nordiska publikationer: www.norden.org/nordpub 


\section{Innehållsförteckning}

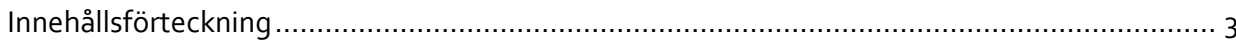

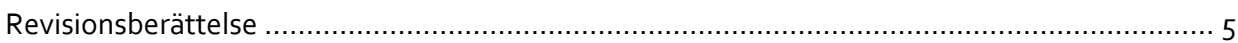

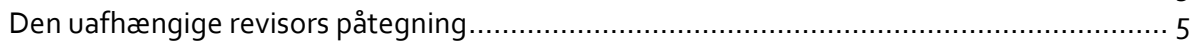

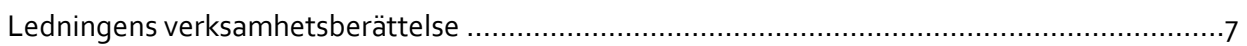

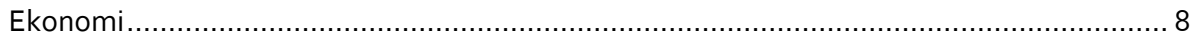

1. Uppföljning av budgetkompromissen med Nordisk Råd 2017 .................................. 9

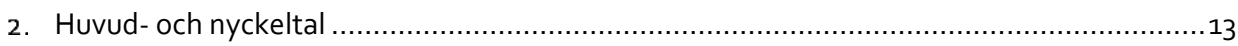

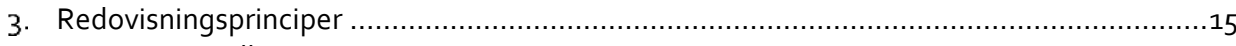

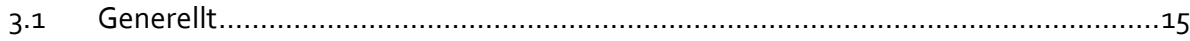

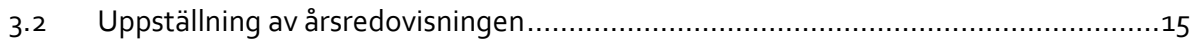

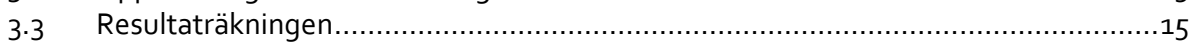

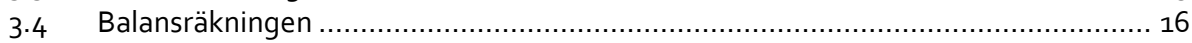

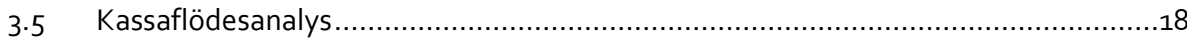

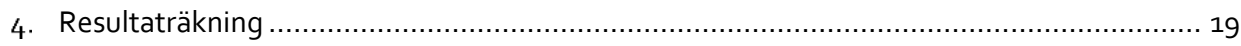

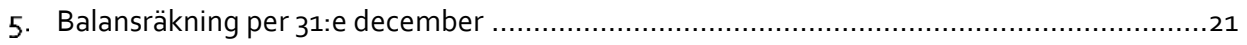

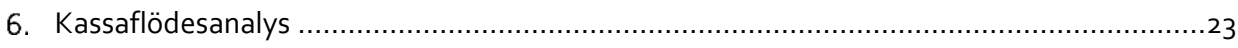

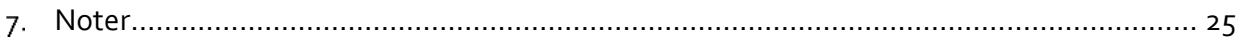

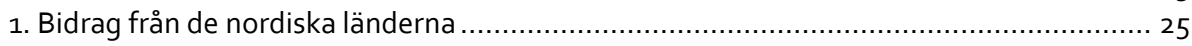

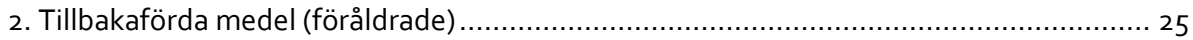

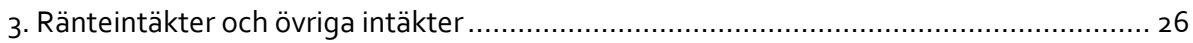

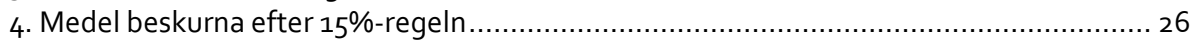

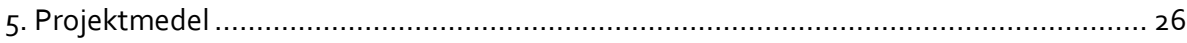

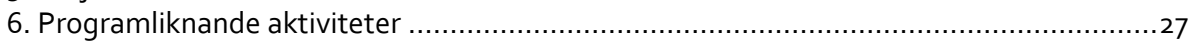

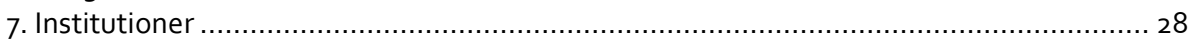

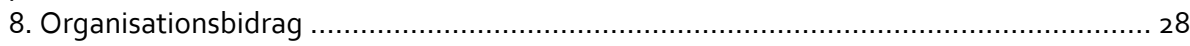

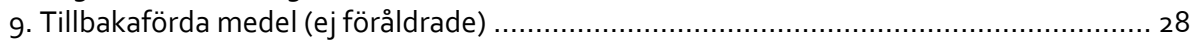

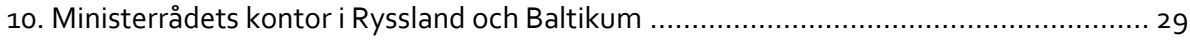

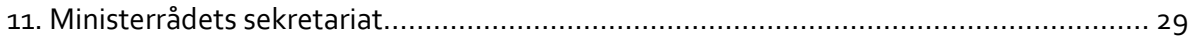

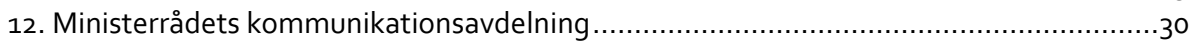

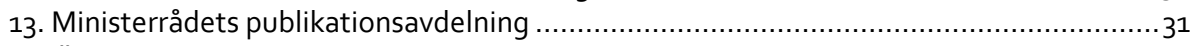

14. Överförda medel (sekretariat, kommunikation och publikation) ….........................32

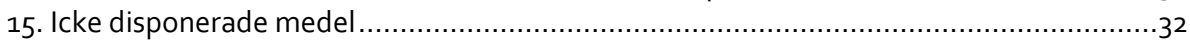

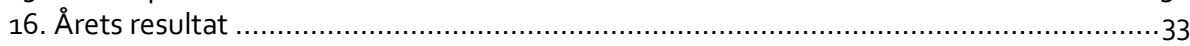

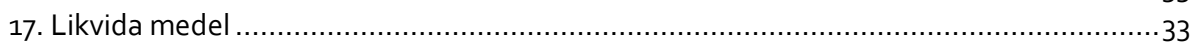

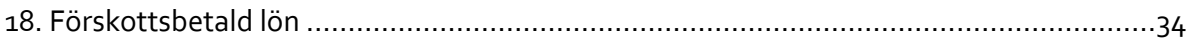

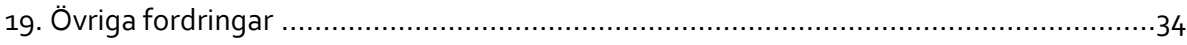

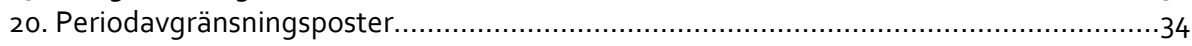

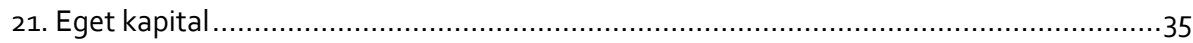

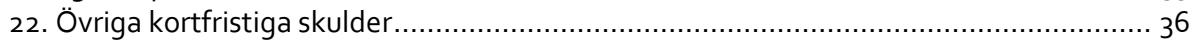

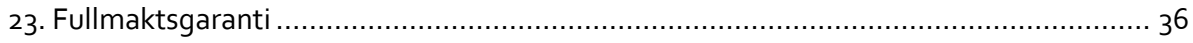

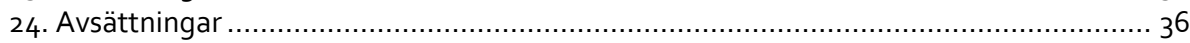

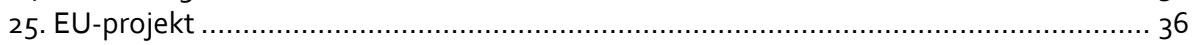

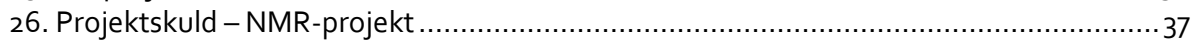

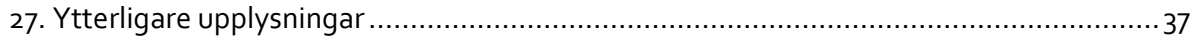

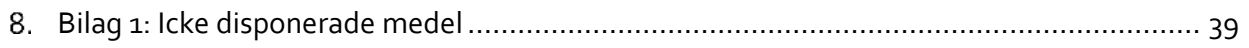

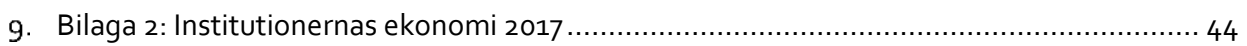


10. Bilaga 3: Riksrevisionens granskningsrapport - Revision af årsregnskabet for $2017 \ldots \ldots \ldots \ldots .46$

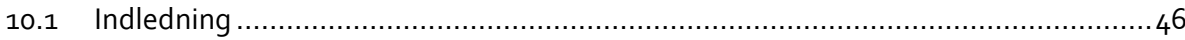

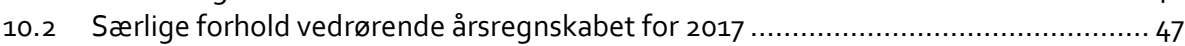

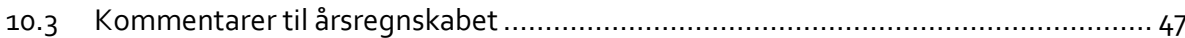

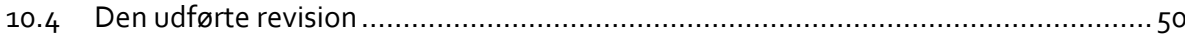

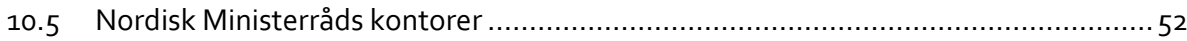

10.6 Revision af Nordisk Ministerråds institutioner, enkeltprojekter mv.......................52

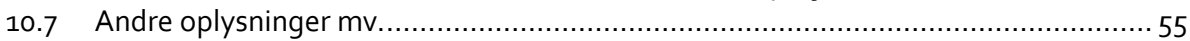




\title{
Revisionsberättelse
}

\author{
Den uafhængige revisors påtegning
}

\section{Til Nordisk Råd og Nordisk Ministerråd}

Vi har revideret årsrapporten for Nordisk Ministerråd for regnskabsåret 1. januar31. december 2017, omfattende ledelsespåtegning, ledelsesberetning, anvendt regnskabspraksis, resultatopgørelse, balance, egenkapitalopgørelse og noter. Årsrapporten aflægges efter Nordisk Ministerråds Økonomireglement og Nordisk Ministerråds udarbejdede forskrifter.

Vi betragter med denne påtegning revisionen af årsrapporten for 2017 som afsluttet. Rigsrevisionen kan dog tage spørgsmål vedrørende dette og tidligere regnskabsår op til yderligere undersøgelser. I den forbindelse kan der fremkomme nye oplysninger, som kan give anledning til, at konkrete forhold, der er behandlet ved denne påtegning, bliver vurderet på ny.

\section{Ledelsens ansvar for årsregnskabet}

Ledelsen har ansvaret for at udarbejde og aflægge en årsrapport, der giver et retvisende billede i overensstemmelse med Nordisk Ministerråds Økonomireglement og Nordisk Ministerråds udarbejdede forskrifter. Ledelsen har endvidere ansvaret for at udforme, implementere og opretholde interne kontroller, der er relevante for at udarbejde en årsrapport, der giver et retvisende billede uden væsentlig fejlinformation, uanset om fejlinformationen skyldes besvigelser eller fejl, samt valg og anvendelse af en hensigtsmæssig regnskabspraksis og udøvelse af regnskabsmæssige skøn, som er rimelige efter omstændighederne. Herudover er det ledelsens ansvar, at de dispositioner, der er omfattet af årsrapporten, er i overensstemmelse med love og andre forskrifter samt med indgåede aftaler og sædvanlig praksis.

\section{Revisorernes ansvar og den udførte revision}

Vores ansvar er at udtrykke en konklusion om årsrapporten på grundlag af vores revision. Vi har udført vores revision i overensstemmelse med god offentlig revisionsskik, jf. lov om revisionen af statens regnskaber $\mathrm{mm}$., og det nordiske revisionsreglement. God offentlig revisionsskik er baseret på de grundlæggende revisionsprincipper i rigsrevisionernes internationale standarder (ISSAI 100-999). Dette indebærer, at det ved revisionen er efterprøvet, om regnskabet er rigtigt, dvs. uden væsentlige fejl og mangler, og om de dispositioner, der er omfattet af regnskabsaflæggelsen, er i overensstemmelse med love og andre forskrifter samt med indgåede aftaler og sædvanlig praksis. 
En revision omfatter handlinger for at opnå revisionsbevis for de beløb og oplysninger, der er anført i årsrapporten. De valgte handlinger afhænger af revisors vurdering, herunder vurderingen af risikoen for væsentlig fejlinformation i årsrapporten, uanset om fejlinformationen skyldes besvigelser eller fejl. Ved risikovurderingen overvejer revisor interne kontroller, der er relevante for Nordisk Ministerråds udarbejdelse af en årsrapport, der giver et retvisende billede. Formålet hermed er at udforme revisionshandlinger, der er passende efter omstændighederne, men ikke at udtrykke en konklusion om effektiviteten af Nordisk Ministerråds interne kontrol. En revision omfatter endvidere vurdering af, om ledelsens valg af regnskabspraksis er passende, og om ledelsens regnskabsmæssige skøn er rimelige, samt en vurdering af den samlede præsentation af årsrapporten. Revisionen omfatter desuden en vurdering af, om der er etableret forretningsgange og interne kontroller, der understøtter, at de dispositioner, der er omfattet af regnskabet, er i overensstemmelse med love og andre forskrifter samt med indgåede aftaler og sædvanlig praksis.

Det er vores opfattelse, at det opnåede revisionsbevis er tilstrækkeligt og egnet som grundlag for vores konklusion.

Revisionen har ikke givet anledning til forbehold.

\section{Konklusion}

Det er vores opfattelse, at årsrapporten giver et retvisende billede af Nordisk Ministerråds aktiver, passiver og finansielle stilling pr. 31. december 2017 samt af resultatet af Nordisk Ministerråds aktiviteter for regnskabsåret 1. januar -31. december 2017 i overensstemmelse med Nordisk Ministerråds Økonomireglement og Nordisk Ministerråds udarbejdede forskrifter. Det er ligeledes vores opfattelse, at der er etableret forretningsgange og interne kontroller, der understøtter, at de dispositioner, der er omfattet af regnskabet, er i overensstemmelse med betingelserne i love og andre forskrifter samt med indgåede aftaler og sædvanlig praksis.

\section{Supplerende oplysning om budgettal i årsregnskabet}

Revisionen har ikke omfattet de i årsregnskabet oplistede budgettal.

København, den 11. juni 2018

Rigsrevisionen

Lone Strøm

Rigsrevisor
Henrik Lange

Kontorchef 


\section{Ledningens verksamhetsberättelse}

2017 var ett bra år för det nordiska samarbetet och Nordiska ministerrådet ser tillbaka på året med tillfredsställelse. Efter flera års arbete med modernisering av samarbetet, kan vi nu se klara resultat av reformerna på flera centrala politikområden, och vi har höjt profilen både inom Norden och internationellt.

De fem statsministrarna var på plats vid lanseringen av statsministerinitiativet Nordic Solutions to Global Challenges i Bergen i Norge i maj. Alla initiativets flaggskeppsprojekt har kommit igång med sitt arbete och vi kan redan nu uppvisa konkreta resultat. T.ex. den nordiska jämställdhetsagendan har fått stor internationell spridning under året, bland annat i samband med FN:s högnivåvecka i september.

I den nordiska paviljongen på COP23 i Bonn i november presenterades flaggskeppsprojekten om hållbart byggande, ny nordisk mat, klimatlösningar och energilösningar. Nordiska ministerrådets program för de globala hållbarhetsmålen, Generation 2030 lanserades också under $\mathrm{COP}_{23}$. Intresset för de nordiska projekten var stort och paviljongen var välbesökt.

De strategiska genomlysningarna har blivit ett välfungerande sätt för ministerrådet att aktivera det politiska samarbetet på centrala samhällsområden. Under 2017 fick vi Jorma Ollilas rapport om det nordiska energisamarbetet; Sterkt idag, sterkare i morgen. När de nordiska energiministrarna möttes i slutet av året enades de, i linje med rapportens rekommendationer, om att eftersträva en enad nordisk linje i förhållande till EU. De beslöt också att samarbetet kring energiforskning måste stärkas.

Under 2017 påbörjades också arbetet med genomlysningarna av miljösamarbetet och socialsamarbetet, samt en genomgång av samarbetet inom lagstiftningsområdet. Alla tre färdigställs och presenteras under 2018. Vi kan räkna med att också de kommer att medverka till att ytterligare fördjupa och förnya det nordiska samarbetet.

Under 2017 fick Nordiska ministerrådet också för första gången på tio år ett nytt ministerråd - Ministerrådet för Digitalisering. Det här är samarbetets sätt att lägga fokus på ett samhällsfenomen där Norden är bland de främsta och önskar vara det också i fortsättningen. Helt konkret vill vi med det nordiska samarbetet bland annat göra det möjligt för näringslivet och medborgarna i de nordiska länderna att använda en unik och säker digital identifiering, ett e-ID, som fungerar oavsett var i regionen de befinner sig. Vi vill också att Norden ska vara drivande i arbetet för införandet av $5 \mathrm{G}$, genom gemensamma standarder och fördelaktiga ramvillkor.

Den analysenhet som Nordiska ministerrådet upprättade i början av 2017 har redan nu levererat flera betydelsefulla rapporter. I rapporten Ett värdefullt samarbete som analysenheten sammanställde utifrån en opinionsundersökning hösten 2017, uppgav 9 av 10 nordiska invånare att de är nöjda eller mycket nöjda med samarbetet, och 6 av 10 önskar att det intensifieras ytterligare. Drygt $60 \%$ av respondenterna sa att deras 
intresse för det nordiska samarbetet har ökat som en direkt konsekvens av den internationella utvecklingen. Ett sådant undersökningsresultat ger ny energi till samarbetet - men det förpliktar också. I enlighet med samarbetsministrarnas vision "Tillsammans är vi starkare" har vi också under 2017 målinriktat arbetat för ökad nordisk nytta, d v s för ett gränslöst, innovativt, synligt och utåtriktat Norden.

\section{Ekonomi}

Nordiska Ministerrådets verksamhet genomförs under 11 ministerråd. Respektive ministerråd omsätter det nordiska samarbetet med egna strategier och program, till vilka det allokeras medel i budgeten. Den nordiska budgeten är alltså uppdelad på de olika ministerråden, och årsredovisningen utgör summan av ministerrådens aktiviteter.

De samlade nettoutgifterna för Nordiska Ministerrådet utgjorde 2017 totalt 938,9 MDKK, och de samlade intäkterna utgjorde 945,5 MDKK. Årets resultat är alltså 10,4 MDKK (2016 var resultatet 10,2 MDKK). Överskottet består av till hälften föråldrade projektmedel som inte är använda inom de tre år som ekonomireglementet kräver samt till hälften av en valutakursvinst.

Under 2017 har likviditeten periodvis varit under press. Orsaken till det kan delvis skyllas på att projekt startat tidigt på året som en följd av reformeringen av projektverksamheten.

När det allokeras medel i budgeten som inte används i budgetåret är dessa medel att betrakta som icke disponerade. Årets icke disponerade medel var 12,3 MDKK vilket motsvarar 1,3 \% av årets budget (för 2016 var 11,2 MDKK icke disponerade).

Årsrapport för 2017 överlämnas härmed.

Köpenhamn den 26 april 2018

Dagfinn Høybråten

Generalsekreterare
Kari Metliaas

Avdelningschef 


\section{Uppföljning av budgetkompromissen med Nordisk Råd 2017}

Nordisk Ministerråds budget för verksamhetsåret 2017 - Förhandlingar med Nordisk Råd och den uppnådda kompromissen.

Hösten 2016 genomfördes politiska förhandlingar mellan Nordiska rådet och Nordiska ministerrådet om ministerrådets budgetförslag, som resulterade i följande ändringar/preciseringar i budgeten för 2017:

- $\quad$ Att avsätta 3,413 MDKK til Nordjobb i 2017.

I 2017 blev det avsatt 3,413 MDKK till Nordjobb. Medlen har använts till Nordjobbs kärnuppgift, som är att öka mobiliteten för unga i Norden på den nordiska arbetsmarknaden och försöka att förbättra språkkunskaper samt kunskaper om nordisk kultur. I 2017 har Nordjobb i övrigt arbetat under et nytt mandat och påbörjat arbetet med rekommendationerna från den externa evalueringen, som genomfördes i 2016.

- Att fortsätta arbeta med den pågående analysen som handlar om samordning och ömsesidig informationsutbyte avseende hälso- och sjukvårdstillstånd i syfte att bedöma säkerheter samt att fördela upp till o,3 MDKK om befintlig finansiering inte är tillräcklig.

Länderna har finansierat revideringen av Överenskommelse om en gemensam nordisk arbetsmarknad för vissa personalgrupper inom hälso- och sjukvårdsväsendet och veterinärer (Arjeplogavtalet) med egna medel under 2017 och har därför inte behövt använda de avsatta medlen. Länderna förväntas fortsatt finansiera den pågående revideringen under 2018 med egna medel.

- I 2017 kommer NMR att genomföra en analys och fördela nödvändiga resurser för att upptäcka om nationella bestämmelser, stödsystem och avgifter $\mathrm{i}$ avfallsområdet främjar eller hämmar uppnåendet av ökat återanvändning av avfall.

Det är avsatt 500000 DKK till en analys av juridiska och ekonomiska instrument med fokus på, om dessa instrument bekräftar eller förvärrar avfallshierarkin i de nordiska 
länderna. Projektet läggas ut i utbud i slutet av 2017 eller början av 2018 och kontrolleras av Miljösektorns avfallsgrupp (NAG). Miljö- och ekonomigruppens (MEG) projekt "Barriers for utilization of bio-waste" är avslutat och resultatet har publicerats i rapporten "Barriers for utilization of bio-waste: Analysis of Institutional barriers for using Biowaste as a resource". Rapporten undersöker oavsiktliga konsekvenser som lagstiftningen och andra formella institutioner kan ha användning av vid biobränsle som resurs.

- Att avsätta 1,o MDKK till att stärka arbetet med samhällssäkerhet i Baltikum och Östersjöregionen.

Nordisk Ministerråd har i 2017 iværksat og videreført projektsamarbejde i Estland, Letland og Litauen indenfor nedenstående områder af betydning for styrkelse af samfundssikkerheden: Nordiska ministerrådet har under 2017 initierat och drivit projektsamarbetet i Estland, Lettland och Litauen för att stärka civilsamhället. Bland annat genom:

- Stöd till och nordiskt deltagande i demokratifestival (motsvarande till "Folkemødet", "Almedalsveckan" m.fl.) 200000 DKK.

- Nordiskt-baltiskt utbyte av erfarenheter om Public service 225000 DKK.

- Nordiskt-baltiskt samarbete om integration av flyktingar 350000 DKK.

Nordiskt engagemang och stöd till oberoende och inkluderande ryskspråkig media 3,8 MDKK. Det har dessutom genomförts nordisk-ryska samarbetsprojekt (ca. 10 MDKK) projekt, som omfattar hela Östersjöregionen (ca. 6 MDKK); i huvudsak med syfte att stärka dcivila samhället. Det noteras att Nordiska ministerrådet enligt Helsingforsavtalet inte utförverksamhet inom försvars- och utrikespolitik.

- Arbetet med bioenergi, inklusive matavfall, fortsätter att vara en viktig del av det nordiska samarbetet. År 2017 genomförs en undersökning för att undersöka möjligheterna till vidareutveckling av nordiskt samarbete inom biobränslen och transport. Studien ska innehålla några förslag från undersökningen om energisektorn som avslutades i mars 2017.

Ett första utkast av rapporten från konsulten, identifiera två möjligheter:

- Bättre sortering av hushållsavfall, som i dag bränns som mixed waste.

- Spill från fiske, fiskodling och köttindustri.

Styrgruppen planerar ett arrangemang i början av 2018, där biobränslen från mat och avfall diskuteras i ett bredare sammanhang: bioekonomi, stopp av matspill, behovet av bioenergi för att ersätta fossila bränslen, produktion av biobränslen i kombination med 
gödsel, användning av matavfall i kombination med boskapsgödsel, halm och andra biologiska rester. Man kommer även diskutera hur man etablerar en ocentraliserad anläggningsstruktur i den relativt spridda nordiska regionen. Deltagare från avfallssektorn, politiker och organisationer kommer delta i arrangemanget.

- Att avsätta upp till 1,0 MDKK för att utreda initiativ gällande mobilitet och rättfärdig konkurrens på arbetsmarknaden och då med särskild fokus på små och mellanstora verksamheter i Baltikum.

Baserat på Nordisk råds rekommendation (3/2016: Mobilitet och rättvis konkurrens) och budgetkompromissen om att avsätta upp till 1,0 MDKK för att utreda om initiativ gällande mobilitet och rättfärdig konkurrens på arbetsmarknaden med särskild fokus på små och mellanstora verksamheter i Baltikum, beställde EK-A en förstudie som utfördes av PRAXSIS - Center for Analyse og Evaluering under våren 2017.

Rekommendationerna från förstudien behandlades på EK-A 02/17, och det togs ett beslut att inte gå vidare med initiativet utöver den förstudie som utförts. EK-A antog att nya informationsinitiativ bör baseras på och hänvisa till befintliga nationella informationstjänster. Det skulle inte vara ändamålsenligt att bygga upp en ny stor tjänst. Det betonades att det inte finns några medel i sysselsättningssektorns budget för att finansiera upprättandet och driften av en sådan tjänst. EK-A rekommenderade att nationella informationstjänster stöds och förstärks snarare än att bygga en ny gemensam nordisk tjänst.

Nordiska rådet önskar även att Nordiska ministerrådet slutar betala tillbaka de oanvända medel som finns kvar vid årsbokslutet och att följande sats därför läggs till i ekonomireglementet:

- Enligt $\ 20 A$ i ekonomireglementet ska medel som inte kan överföras till nästa räkenskapsår återbetalas till länderna (fr.o.m 2009) tills NMR har återbetalat 35 MDKK - sedan deponeras dessa medel på ett reservkonto till MR-SAM:S förfogande för nästa budgetår.

Efter räkenskapsåret 2015 har man betalat tillbaka 30,2 MDKK. Det förväntas att resten av medlen betalas tillbaka med de i 2016 oanvända medlen, och att det från och med 2018 sätts medel på dispositionskonto. 


\section{Huvud- och nyckeltal}

Utvalda huvud- och nyckeltal för Nordiska ministerrådet de senaste fyra åren

\begin{tabular}{|c|c|c|c|c|}
\hline & 2017 & 2016 & 2015 & 2014 \\
\hline \multicolumn{5}{|l|}{ Utgiftsram } \\
\hline \multicolumn{5}{|l|}{ Intäkter: (TDKK) } \\
\hline - Danmark & 186161 & 177441 & 183636 & 197844 \\
\hline - Finland & 145611 & 143599 & 142318 & 153565 \\
\hline - Island & 8294 & 7317 & 6427 & 6595 \\
\hline - Norge & 292144 & 295431 & 289227 & 288287 \\
\hline - Sverige & 289380 & 290857 & 296573 & 295824 \\
\hline - Avgift av lön, räntor och övriga intäkter & 23955 & 23099 & 32958 & 38644 \\
\hline Summa & 945545 & 937744 & 951139 & 980759 \\
\hline \multicolumn{5}{|l|}{ Årets resultat } \\
\hline Intäkter minus utgiftsram & 10454 & 10199 & 19357 & 25544 \\
\hline \multicolumn{5}{|l|}{ Ländernas bidrag - fördelning per land } \\
\hline - Danmark & $20,2 \%$ & $19,4 \%$ & $20,0 \%$ & $21,0 \%$ \\
\hline - Finland & $15,8 \%$ & $15,7 \%$ & $15,5 \%$ & $16,3 \%$ \\
\hline - Island & $0,9 \%$ & $0,8 \%$ & $0,7 \%$ & $0,7 \%$ \\
\hline - Norge & $31,7 \%$ & $32,3 \%$ & $31,5 \%$ & $30,6 \%$ \\
\hline - Sverige & $31,4 \%$ & $31,8 \%$ & $32,3 \%$ & $31,4 \%$ \\
\hline \multicolumn{5}{|l|}{ Behållning per 31/12 } \\
\hline Icke disponerade medel & 12341 & 11182 & 17623 & 16405 \\
\hline Likvida medel & 203753 & 186871 & 182655 & 124971 \\
\hline Eget kapital & -109546 & -109801 & -100643 & -94456 \\
\hline \multicolumn{5}{|l|}{ Övriga } \\
\hline Icke disponerade medel, $\%$ av årets budget & $1,3 \%$ & $1,2 \%$ & $1,9 \%$ & $1,7 \%$ \\
\hline Sekretariatets drift, \% av årets budget & $9,0 \%$ & $8,4 \%$ & $8,3 \%$ & $7,9 \%$ \\
\hline Antal institutioner & 12 & 12 & 13 & 14 \\
\hline Antal anställda på Nordiska villkor & 99 & 93 & 97 & 95 \\
\hline - Härav kvinnor & 60 & 56 & 57 & 60 \\
\hline - Härav män & 39 & 37 & 40 & 35 \\
\hline
\end{tabular}




\section{Redovisningsprinciper}

\subsection{Generellt}

Nordiska Ministerrådet baserar årsredovisningen på den modifierade bokföringsprincip som innebär att alla utgifter och intäkter tas upp i det budgetår de hör till. Detta är oförändrat jämfört med tidigare år.

Årsredovisningen är avlagd i överensstämmelse med bokföringsbestämmelserna i Nordiska ministerrådets Ekonomireglemente. Använd bokföringspraxis vad gäller värderingsmetoder med mera är oförändrade i förhållande till tidigare år.

\subsection{Uppställning av årsredovisningen}

I samband med upprättande av årsredovisningen har utgångspunkt tagits i de aktivitetsområden som är fokus i de mottagna beviljningarna. Där det bedömts relevant har drift av enskilda aktivitetsområden specificerats i not. Medel på budgetposterna indelas i projektmedel, programliknande aktiviteter, institutioner samt organisationsbidrag.

\subsection{Resultaträkningen}

\subsubsection{Avgränsning}

Alla intäkter och utgifter som avser aktuell period medräknas i resultaträkningen oavsett betalningstidpunkt.

Transaktioner i utländsk valuta omräknas till danska kronor efter transaktionsdagens kurs. Tillgångar och skulder i utländsk valuta omräknas till danska kronor efter balansdagens kurs. Valutakursregleringar som uppstår på grund av skillnader i valutakurs på transaktionsdag och balansdag medräknas i resultaträkningen.

\subsubsection{Inbetalningar från de nordiska länderna}

Respektive lands bidrag till den totala budgeten beräknas på grundval av landets andel av ländernas totala bruttonationalinkomst. Länderna inbetalar ett belopp som motsvarar aktivitetsramen med avdrag för avgift av lön, nettoränteintäkter samt övriga intäkter. 


\subsubsection{Tillbakabetalade medel (föråldrade)}

Medel som inte är använda senast tre år efter beviljande (föråldrade medel) betalas enligt Nordiska ministerrådets ekonomireglemente tillbaka till länderna. Betalningen genomförs i samband med tillbakabetalningen av årets resultat, om MR-SAM träffar beslut om detta i samband med godkännandet av årsrapporten.

\subsubsection{Tillbakaförda medel}

Tillbakaförda medel är medel som har tillbakaförts från aktiviteter som antingen har utförts till lägre kostnad än beviljat belopp eller som ej har genomförts. Alla tillbakaförda medel som inte är föråldrade avseende 3 -årsregeln används under verksamhetsåret.

\subsubsection{Avgift av lön}

Nordiska ministerrådets anställda betalar avgift på lön enligt det interna avgiftssystemet. Avgiften ingår som finansiering av den fastställda utgiftsramen för Nordiska ministerrådets aktiviteter.

\subsection{6 Övriga intäkter}

Andra intäkter innehåller poster av sekundär karaktär i förhållande till Nordiska ministerrådets huvudaktiviteter, härunder valutakursregleringar.

\subsubsection{Icke disponerade medel/överförda medel}

De av årets budget ej använda medlen (icke disponerade medel) överförs till kommande års aktiviteter som överförda medel. Enligt ekonomireglementet är dock överföringen begränsad till maximalt $15 \%$ av årets budget.

\subsection{8 Årets resultat}

Årets resultat beräknas som skillnaden mellan de budgeterade och de faktiska beloppen på följande poster: avgift av lön, ränteintäkter, övriga intäkter och föråldrade medel.

\subsection{Balansräkningen}

\subsubsection{Likvida medel}

Likvida medel är behållning i bank. Likvider i utländsk valuta är medräknat i danska kronor till balansdagens kurs. 


\subsubsection{Fordringar}

Tillgodohavanden upptas normalt till nominellt värde. Vid behov sker nedskrivning efter individuell bedömning om risk för förluster.

\subsubsection{Mellanräkning med EU/projektskuld externa EU-projekt}

Mellanräkning med EU avser ingångna kontrakt för drift av projekten Civil Society Stability for Belarus (CSSB) och Open Europe Scholarship Scheme (OESS). Förpliktelse och tillgodohavande för dessa ingångna kontrakt är medtaget i balansen. Tillgodohavande avskrives i takt med att Nordiska Ministerrådet mottar inbetalningar från EU, och förpliktelsen nedskrives i takt med utbetalningar till projekten.

\subsubsection{Periodavgränsningsposter}

Periodavgränsningsposter under tillgångar omfattar avhållna kostnader avseende nästa verksamhetsår. Detta utgör normalt förutbetalda omkostnader för hyra, licensavtal, med mera. Här finns även årets fordran på länderna för den fullmaktsgaranti som tas upp under kortfristig skuld.

\subsubsection{Leverantörsskulder och annan skuld}

Skuld till leverantörer tas upp till nominellt värde. Skuld i utländsk valuta upptas till balansdagens kurs.

\subsubsection{Avsättningar}

Det avsätts medel när Nordiska ministerrådet har en faktisk förpliktelse, och det är sannolikt att infriandet av förpliktelse kommer medföra användning av ekonomiska medel. Förpliktelsens belopp avsätts till det belopp förpliktelsen uppskattas att infrias till.

\subsubsection{Investeringar}

Alla investeringar i anläggningstillgångar utgiftsförs fullt ut i anskaffningsåret.

\subsection{8 Överförda medel}

Av mindre förbrukning (icke disponerade medel) på budgetposter kan det överföras ett belopp svarande till maximalt $15 \%$ av årets beviljning till efterföljande budgetår. Om budgetposten är under 1 MDKK så kan det dock överföras upp till 150 TDKK utan att medel beskärs. Medel överförs mellan budgetår på budgetpostnivå enligt principen att äldst medel används först (FIFO).

Icke disponerade medel som ej kan överföras enligt ovanstående återbetalas till länderna till dess Nordiska ministerrådet har återbetalt 35 MDKK. Detta sker efter den fördelningsnyckel som gällde 2008. 


\subsubsection{Fullmaktsgaranti (tilsagnsfuldmagt)}

Det förekommer i undantagsfall att nordiska institutioner har fullmakt att förpliktiga medel $\mathrm{i}$ kommande års budget, och att då dessa medel garanteras av ministerrådet upp till ett maximalt belopp. Den del av fullmakten som faktiskt har förpliktigats av institutionen tas upp som skuld i ministerrådets balansräkning, och motsvarande belopp tas upp som fordran på länderna som periodavgränsningspost. Vid normal fortsatt drift infrias aldrig varken fullmaktsgaranti eller fordran på länderna.

\subsection{Kassaflödesanalys}

Kassaflödesanalysen är uppställd enligt indirekt metod, och likviditet består av banktillgodohavanden. 


\section{Resultaträkning}

\begin{tabular}{|c|c|c|c|c|}
\hline (TDKK) & Not & 2017 & Budget 2017 & 2016 \\
\hline \multicolumn{5}{|l|}{ Intäkter } \\
\hline $\begin{array}{l}\text { Länderna } \\
\text { Bidrag från de nordiska länderna } \\
\text { Andra intäkter }\end{array}$ & 1 & 921591 & 921591 & 914646 \\
\hline Tillbakaförda medel (föråldrade) & 2 & 5536 & o & 6165 \\
\hline Avgift av lön & & 13455 & 13500 & 12902 \\
\hline Ränteintäkter & 3 & o & o & 246 \\
\hline Övriga intäkter & 3 & 4923 & o & 1917 \\
\hline Medel beskurna efter $15 \%$ regeln & 4,22 & 422 & o & 2239 \\
\hline Summa intäkter & & 945927 & 935091 & 938115 \\
\hline Valutakursförluster, ränteutgifter och övriga utgifter & & -382 & 0 & -370 \\
\hline Nettofinansiering av årets aktiviteter & & 945545 & 935091 & 937745 \\
\hline \multicolumn{5}{|l|}{ Utgifter } \\
\hline Projektmedel 7 & 5 & 160412 & 141376 & 139176 \\
\hline Programliknande aktiviteter & 6 & 406667 & 399574 & 427234 \\
\hline Institutioner & 7 & 273835 & 273835 & 278924 \\
\hline Organisationsbidrag & 8 & 24979 & 25284 & 24595 \\
\hline Tillbakaförda medel (ej föråldrade) & 9 & -27018 & 0 & -30018 \\
\hline Ministerrådets kontor i Ryssland och Baltikum & 10 & 15814 & 15778 & 15926 \\
\hline Ministerrådets sekretariat & 11,12 & 84367 & 79244 & 77827 \\
\hline Ministerrådets publikationsavdelning & 13 & -76 & 232 & 142 \\
\hline Summa utgifter & & 938979 & 935323 & 933806 \\
\hline \multicolumn{5}{|l|}{ Ändring överförda medel } \\
\hline Sekretariat, publikation och kommunikation & 14 & -5047 & o & 181 \\
\hline Icke disponerade medel & 15 & 1159 & oo & -6441 \\
\hline Summa ändring överförda medel & & -3888 & o & -6260 \\
\hline Årets resultat & 16 & 10454 & 0 & 10199 \\
\hline
\end{tabular}

Note: De totala utgifterna (exkl. räntor) utgjorde 2017 totalt 939 MDKK (2016: 934 MDKK). 


\section{Balansräkning per 31:e december}

\begin{tabular}{|c|c|c|c|}
\hline (TDKK) & Note & 2017 & 2016 \\
\hline \multicolumn{4}{|l|}{ Tillgångar } \\
\hline \multicolumn{4}{|l|}{ Omsättningstillgångar } \\
\hline \multicolumn{4}{|l|}{ Likvida medel } \\
\hline \multirow[t]{2}{*}{ Innestående i bank } & 17 & 203753 & 186871 \\
\hline & & 203753 & 186871 \\
\hline \multicolumn{4}{|l|}{ Fordringar } \\
\hline Personalfordringar & & 203 & 149 \\
\hline Förskottsbetald lön & 18 & 3615 & 3431 \\
\hline Övriga fordringar & 19 & 5820 & 10028 \\
\hline Mellanräkning med EHU Trust Fund & & 0 & 625 \\
\hline Mellanräkning med EU & & o & 774 \\
\hline \multirow[t]{2}{*}{ Periodavgränsningsposter } & 20,22 & 10019 & 73561 \\
\hline & & 19657 & 88568 \\
\hline Summa omsättningstillgångar & & 223409 & 275439 \\
\hline Summa tillgångar & & 223409 & 275439 \\
\hline
\end{tabular}

Note: Likvida medel utgjorde per 31.12.2017 totalt 204 MDKK (2016: 187 MDKK). Samarbetsministrarna beslutade 2007 att reducera likviditeten med 70 MDKK genom en reduktion av inbetalningarna under 2008. För att hålla likviditeten på en låg nivå har MR-SAM beslutat att ländernas inbetalningar sker åtta gånger årligen, i början och i slutet av varje kvartal. 


\section{(TDKK)}

Skulder

Eget kapital

Årets resultat

Tillbakabetalning av utökad ram

Reducerad inbetalning

Tidigare avskrivet krav på länderna
21

$\begin{array}{rr}10032 & 7960 \\ 422 & 2239 \\ -70000 & -70000 \\ -50000 & -50000\end{array}$

\begin{tabular}{|c|c|c|c|c|}
\hline Summa eget kapital & & -109546 & -109801 & \\
\hline $\begin{array}{l}\text { Överförda medel } \\
\text { Icke disponerade medel } \\
\text { Icke använda medel (sekretariat och publikation) }\end{array}$ & $\begin{array}{l}15 \\
14\end{array}$ & $\begin{array}{l}12341 \\
20596\end{array}$ & $\begin{array}{l}11182 \\
25643\end{array}$ & \\
\hline Summa överförda medel & & 32937 & 36595 & \\
\hline \multicolumn{5}{|l|}{ Kortfristig skuld } \\
\hline Övriga kortfristiga skulder & 22 & 9678 & 792 & 792 \\
\hline Fullmaktsgaranti & 23 & 5523 & 41187 & 41187 \\
\hline Personalförpliktelser & & 5021 & 3690 & 3690 \\
\hline Avsättningar & 24 & 2550 & 2200 & 2200 \\
\hline Projektskuld - EU projekt & 25 & 2373 & 289 & 289 \\
\hline Projektskuld - NMR projekt & 19,26 & 254724 & 278350 & 278350 \\
\hline Summa kortfristig skuld & & 300018 & 348415 & 348415 \\
\hline Summa skulder & & 223409 & 275439 & \\
\hline Ytterligare upplysningar & 27 & & & \\
\hline
\end{tabular}

Note: Nordiska Ministerrådets eget kapital utgjorde 31.12.2017 totalt -110 MDKK. Det negativa egenkapitalet har uppstått på grund av ovan nämnda reduktion av inbetalningar samt tidigare avskrivet krav på länderna. Därtill läggs årets resultat. Det negativa egenkapitalet ska i enlighet med ekonomireglementet utjämnas genom inbetalningar från länderna när likviditeten så kräver.

Icke disponerade medel utgör vid utgången av 2017 totalt 12,3 MDKK vilket ligger på samma nivå som föregående år (2016: 11,1 MDKK). Medlen ingår i finansiering av aktiviteter 2018, och en översikt över icke disponerade medel finns i bilaga 1. 


\title{
6. Kassaflödesanalys
}

Driftens likviditetspåverkan

\author{
Årets resultat \\ Intäkter \\ Utgifter \\ Resultat tillbaka till länderna \\ Driftsaktiviteter \\ Fordringar, periodavgränsningsposter och förutbetalningar \\ Mellanräkning med EU \\ Kortfristig skuld \\ Projektskuld - externa projekt \\ Projektskuld - NMR projekt \\ Mellanräkning med EHU Trust Fund \\ Kontantström från driftssaktiviteter \\ Finansiering \\ Resultat tillbakabetalt till länderna \\ Kontantstöm från finansiering \\ Likvid behållning 1/1 \\ Kontantström från driftsaktiviteter \\ Likvid behållning 31/12
}

945545

$-938979$

937745

$-10199$

$-933806$

$67513 \quad-58488$

$774 \quad 2574$

$-26855 \quad 53670$
2084

$2084 \quad-2833$

$-23626 \quad 25074$

$\begin{array}{rr}625 & -362 \\ 27080 & 23573\end{array}$




\section{Noter}

\section{Bidrag från de nordiska länderna}

Ländernas bidrag 2017 och 2016 utgjorde.

\begin{tabular}{lrrrr} 
(TDKK) & 2017 & Andel & 2016 & Andel \\
Danmark & 186161 & $20,2 \%$ & 177441 & $19,4 \%$ \\
Finland & 145611 & $15,8 \%$ & 143599 & $15,7 \%$ \\
Island & 8294 & $0,9 \%$ & 7317 & $0,8 \%$ \\
Norge & 292144 & $31,7 \%$ & 295431 & $32,3 \%$ \\
Sverige & 289380 & $31,4 \%$ & 290857 & $31,8 \%$ \\
& & & & \\
Summa & $\mathbf{9 2 1} 591$ & $\mathbf{1 0 0 , 0 \%}$ & $\mathbf{9 1 4 6 4 6}$ & $\mathbf{1 0 0 , 0 \%}$ \\
\hline
\end{tabular}

Nordiska Ministerrådets samlade budget var 2017 totalt 935 MDKK (2016: 928 MDKK), som är en oförändrad ram i jämförelse med budget 2016. Till budgetramen läggs en valuta och prisjusteringseffekt.

Budgeten finansieras primärt med inbetalningar från länderna, som 2017 utgjorde 922 MDKK. Därutöver tillkommer intäkter från intern avgift på löneutbetalningar, ränteintäkter, medel beskurna enligt ekonomireglementets \$20, samt övriga intäkter. 2017 var summan av dessa intäkter 24 MDKK (budget 2016: 13 MDKK). Skillnaden mellan dessa belopp utgör årets resultat; ett överskott på 10 MDKK som kan återbetalas till länderna. Överskottet utgörs i huvudsak av föråldrade projektmedel som inte är använda inom treårsfristen.

\section{Tillbakaförda medel (föråldrade)}

Medel som återstår på ett projekt tre år efter disponeringsårets start är enligt ekonomireglementet föråldrade. Oftast handlar det om att förvaltningsorganet ej kunnat genomföra hela projektet i tid, eller att projektet kunnat genomföras till en lägre kostnad än budgeterat. Dessa återförda medel blir en del av ministerrådets resultat, som återbetalas till länderna om MR-SAM så beslutar i samband med godkännande av årsrapporten. 


\section{Ränteintäkter och övriga intäkter}

Ränteintäkter består av ränta på likvidbehållning på konton hos Nordea. Övriga intäkter består primärt av valutakursvinster då likvida behållningar räknats om till balansdagens kurs. Konton i DKK, EUR och SEK har under året haft negativ ränta.

Årets intäkt beror på en valutavinst vid betalning av ministerrådets skuld till Nordforsk iNOK.

\section{Medel beskurna efter 15\%-regeln}

Medel beskurna efter ekonomireglementets 15\%-regel används till att reducera den ramutvidgning på 35 MDKK som genomfördes 2008. Totalt har nu ramutvidgningen reducerats med 33 MDKK inklusive medel för 2017.

Beskurna medel fördelat per ministerråd.

\begin{tabular}{lrrrrr} 
& 2017 & 2016 & $\mathbf{2 0 1 5}$ & $\mathbf{2 0 1 4}$ & $\mathbf{2 0 1 3}$ \\
Samarbetsministrarna & & & & \\
MR - Kulturpolitik & 421 & 1505 & 6229 & 4169 & 6009 \\
MR - FJSL & 0 & 0 & 342 & 306 & 0 \\
MR - Utbildning och forskning & 0 & 0 & 0 & 103 & 0 \\
MR - Näring, Energi och Regionalpolitik & 0 & 0 & 0 & 56 & 364 \\
MR - Miljö & 0 & 0 & 0 & 37 & 0 \\
MR - Lagstiftning & 0 & 0 & 0 & 84 & 0 \\
& 0 & 734 & 28 & 45 & 0 \\
Summa & & & & & \\
\hline
\end{tabular}

Av ekonomireglementet framgår även att icke disponerade medel överstigande $15 \%$ av årets beviljning ska tillbaka betalas till länderna. För budgetposter under 1 MDKK gäller dock att det alltid kan överföras 150 TDKK till efterföljande år. Tillbakabetalningen till länderna ska ske till dess Nordiska ministerrådet har återbetalt den ramutvidgning på 35 MDKK som företogs 2008 för att finansiera globaliseringsinitiativen. Det kommer efter betalning för 2017 att ha tillbakabetalats totalt 33 MDKK.

\section{Projektmedel}

Utgifter till projekt, programliknande aktiviteter, institutioner och organisationsbidrag utgjorde 2017 totalt 865,9 MDKK (2016: 869,9 MDKK), se not 5-8. Till drift av Nordiska Ministerrådets Sekretariat samt publikations- och kommunikationsavdelningen användes 84,3 MDKK (2016: 77,7 MDKK), se not 11-13.

De använda projektmedlen fördelat per ministerråd. 


\begin{tabular}{lrr} 
& 2017 & 2016 \\
Prioriteringsbudget & 37861 & 20537 \\
Samarbetsministrarna & 16711 & 13724 \\
Internationellt samarbete & 22715 & 23839 \\
MR-Utbildning och forskning & 13666 & 12198 \\
MR-Social- och hälsovårdspolitik & 12188 & 11708 \\
MR-Kultur & 12614 & 11589 \\
MR-FJSL & 12943 & 12744 \\
MR-Jämställdhet & 7101 & 7762 \\
MR-NER & 12706 & 13077 \\
MR-Miljö & 5681 & 4433 \\
MR-Arbetsmarknad & 2716 & 2565 \\
MR-Ekonomi och finanspolitik & 1832 & 2069 \\
MR-Lagstiftning & 1670 & 2817 \\
Globalisering & 8 & 116 \\
& & 139176 \\
\hline Summa & 160412 & \\
\hline
\end{tabular}

Av totalt använda medel användes 16,6 \% på projekt (2016: 14,4 \%), 42,1 \% till programliknande aktiviteter (2016: 44,3\%), 28,3\% till utbetalningar till de nordiska institutionerna (2016: 28,9\%), 2,6\% till bidrag till organisationer (2016: 2,6\%) och 1,6\% till Nordiska Ministerrådets kontor i Baltikum (2016: 1,7\%). De resterande 8,7 \% användes till driften av Nordiska Ministerrådets sekretariat samt publikations- och kommunikationsavdelningen (2016: 8,1\%).

\section{Programliknande aktiviteter}

Programliknande aktiviteter innehåller samarbetsorgan, program, bidragsordningar och arbetsgrupper.

Använda medel fördelar sig per ministerråd.

\begin{tabular}{lrr} 
& 2017 & 2016 \\
Prioriteringsbudget & 63665 & 63161 \\
Samarbetsministrarna & 14920 & 14591 \\
Internationellt samarbete & 19814 & 43731 \\
MR-Utbildning och forskning & 110984 & 108055 \\
MR-Social- och hälsovårdspolitik & 9123 & 9962 \\
MR-Kultur & 107071 & 104847 \\
MR-FJSL & 7545 & 9073 \\
MR-Jämställdhet & 2627 & 2581 \\
MR-NER & 26176 & 25582 \\
MR-Miljö & 36272 & 36732 \\
MR-Arbetsmarknad & 8470 & 8919 \\
Globalisering & 0 & 0 \\
& & 427234 \\
l alt & 406667 & 427 \\
\hline
\end{tabular}




\section{Institutioner}

De nordiska institutionerna mottog basbeviljning i DKK under räkenskapsåren 2017 och 2016. För ytterligare information om institutionernas ekonomi hänvisas till bilaga 2.

\begin{tabular}{lrr} 
& 2017 & 2016 \\
NordForsk & 99442 & 104153 \\
Nordisk Välfärdscenter (NVC) & 20083 & 19794 \\
Norden hus på Färöarna (NHFÖ) & 13692 \\
Nordens hus i Reykjavik & 13884 & 9880 \\
Nordens institut på Grönland (NAPA) & 11148 & 6417 \\
Nordens institut på Åland (NIPÅ) & 6507 & 2973 \\
Kulturkontakt Nord (KKN) & 3023 & 11257 \\
Nordisk Genressource Center & 11448 & 19484 \\
Nordisk Innovation & 19769 & 70326 \\
Nordisk Energiforskning (NEF) & 67910 & 6261 \\
Nordregio & 6046 & 11284 \\
Institutet för vidareutbildning inom arbetsmiljö (NIVA) & 11114 & 3403 \\
& 3461 & 278924 \\
\hline lalt & & 273835 \\
\hline
\end{tabular}

\section{Organisationsbidrag}

\begin{tabular}{lrr} 
& 2017 & 2016 \\
\hline Föreningarna Nordens Förbund & 3341 & 3282 \\
Bidrag till Västnorden & 750 & 737 \\
NORDICOM & 2997 & 2944 \\
Prioriterade verksamheter & 2795 & 2803 \\
Samiskt samarbete & 3891 & 3822 \\
Svanen & 4347 & 4270 \\
NORA & 6858 & 6737 \\
& & $\mathbf{2 4 5 9 5}$ \\
I alt & $\mathbf{2 4 9 7 9}$ & \\
\hline
\end{tabular}

NORDICOM är från och med 1 januari 2016 omlagt från att vara institution till samarbetsorgan.

\section{Tillbakaförda medel (ej föråldrade)}

Tillbakaförda medel är medel från aktiviteter som har avhållits till en lägre kostnad än det beviljade beloppet, eller från aktiviteter som ej har genomförts. Följande belopp blev tillbakafört under 2017 respektive 2016. Då medlen ej är förfallna enligt 3-årsregeln används de under året till finansiering av Nordiska ministerrådets aktiviteter. 


\section{Ministerrådets kontor i Ryssland och Baltikum}

Följande belopp har använts 2017 respektive 2016.

\begin{tabular}{lrr} 
& 2017 & 2016 \\
Sankt Petersburg och Kaliningrad & 2410 & 2793 \\
Estland & 4000 & 4215 \\
Lettland & 4000 & 4409 \\
Litauen & 4150 & 4290 \\
Tvärgående insatser och projekt & 1254 & 214 \\
& & $\mathbf{1 5 8 1 4}$ \\
Summa & $\mathbf{1 5 9 2 1}$ \\
\hline
\end{tabular}

Aktiviteterna i kontoren i Ryssland har reducerats till ett minimum från2015 på grund av den politiska situationen i landet och de konsekvenser detta haft för ministerrådets verksamhet. Det finns fortsatt en representation i Sankt Petersburg som upprätthåller det minimum av aktiviteter som följer av samarbetsavtal med ryska myndigheter.

\section{Ministerrådets sekretariat}

Nordiska ministerrådets sekretariat har budgetpost nummer 1-0180 i Nordiska ministerrådets budget. 
Intäkter

Nordiska Ministerrådets budget

Övriga intäkter

Summa intäkter

$\begin{array}{lll}79244 & 79244 & 78150\end{array}$

$11463 \quad 9500 \quad 10977$

Utgifter

Personalrelaterade omkostnader

Lokaler och andra sekretariatsomkostnader

Verksamhets- och kompetensutveckling

Kommunikationsavdelningen

Faktiskt använt av överförda medel

Summa utgifter

90707

88744

\begin{tabular}{lrrr} 
Årets resultat & -5123 & -5236 & 323 \\
& & 79244 & 78150 \\
Årets budget & 79244 & 6000 & -323 \\
Överförda medel från tidigare år & 6000 & -5236 & 77827 \\
Faktiskt använt & -5123 & 80008 & 80121 \\
Summa & & 823 & \\
\hline
\end{tabular}

Note: *Kostnaderna bokförda på konton som hänför till kostnaden.

Sekretariatets intäkter består primärt av administrationsbidrag från Nordiska Kulturfonden (baserat på 5 årsverk), Nordiska rådet (baserat på 15 årsverk), Kommunikationsavdelningen (baserat på 15 årsverk) samt från projektanställda medarbetare (uppkrävs för de som är anställda i projekt i sekretariatet mer än tre månader). I årets resultat för sekretariatet ingår kostnadstäckning av kommunikationsavdelningens negativa resultat för året.

\section{Ministerrådets kommunikationsavdelning}

Kommunikationsavdelningen tillvaratar både det dagliga och det långsiktiga arbetet med kommunikations- och informationsverksamhet samt tolkning i Nordiska ministerrådet och Nordiska rådet. Kommunikationsavdelningen finansieras av Nordiska ministerrådet med 60 \% och av Nordiska rådet med $40 \%$. Årets underskott om 410 TDKK täcks av ministerrådets sekretariat och resultatet ingår därför som en del av not 11. 
Intäkter

Nordiska ministerrådets budget

Nordiska rådets budget

Summa intäkter

\section{Utgifter}

Personalrelaterade omkostnader

Administration

Web

Andra utgifter

$9354 \quad 9000 \quad 9166$

Summa utgifter

16610

16200

\section{Ministerrådets publikationsavdelning}

Publikationsavdelningen optimerar distribution och förmedling av Nordiska ministerrådets publikationer mot ett flertal målgrupper, härunder särskilt ämbetsmän och politiker, forskare och studerande samt NGO:S, näringsliv och media. Grafisk formgivning utförs även av en rad andra produkter såsom utställningsmaterial, merchandise, innehåll till sociala medier och mallar. Därutöver ges råd och information om organisationens visuella identitet, och designmanualen hålls löpande uppdaterad.

Enheten täcker sina utgifter genom försäljning av service och publikationer och omsättningen kommer till största del från intern fakturering till Nordiska ministerrådet, samt till Nordiska rådet, institutioner och samarbetsorgan. Alla publikationer är fritt tillgängliga för nedladdning i PDF-format (open access), medan tryckta publikationer säljs via NMRs distributör samt som e-böcker via ett antal internationella kanaler.

\begin{tabular}{|c|c|c|c|}
\hline & 2017 & Budget 2017 & 2016 \\
\hline \multicolumn{4}{|l|}{ Intäkter } \\
\hline Summa intäkter & 4632 & 4308 & 4057 \\
\hline \multicolumn{4}{|l|}{ Utgifter } \\
\hline Personalrelaterade omkostnader & -2264 & -2147 & -2026 \\
\hline Publiceringsutgifter & -2031 & -2183 & -1993 \\
\hline Övriga utgifter & -262 & -210 & -240 \\
\hline Summa utgifter & -4557 & -4540 & -4199 \\
\hline Årets resultat & 76 & -232 & -142 \\
\hline
\end{tabular}




\section{4. Överförda medel (sekretariat, kommunikation och publikation)}

Icke använda medel för sekretariat, kommunikation och publikation kan uppställas enligt nedanstående.

\begin{tabular}{lcccc} 
& $\begin{array}{r}\text { Sekretariat } \\
\text { (not 11) }\end{array}$ & $\begin{array}{r}\text { Kommunikation } \\
(\text { not 12) }\end{array}$ & $\begin{array}{r}\text { Publikation } \\
\text { (not 13) }\end{array}$ & Total \\
\hline Överförda medel 1.1.2016 & 25643 & 0 & 0 & 25643 \\
\hline Årets resultat & -4713 & -410 & 76 & -5047 \\
\hline Överförda medel 31.12.2017 & 20930 & -410 & 76 & 20596 \\
\hline
\end{tabular}

\section{Icke disponerade medel}

De per 31 december icke disponerade medlen kan sammanställas.

\begin{tabular}{lrrr} 
& 2017 & 2016 & Skillnad \\
Budget & 935091 & 927546 & 7545 \\
+ överfört från tidigare år & 11182 & 17622 & -6440 \\
+ tillbakaförda medel från projekt & 27018 & 30018 & -3000 \\
- använda medel & -960950 & -964004 & 3054 \\
& & & 1159 \\
\hline Summa icke disponerade medel & $\mathbf{1 2 3 4 1}$ & $\mathbf{1 1 1 8 2}$ & $\mathbf{1 1 8 2}$ \\
\hline
\end{tabular}

De icke disponerade medlen (mindre förbrukning på budgetposter av projektmedel, program och organisationsbidrag) används till finansiering av kommande års aktiviteter på budgetpostnivå. Enligt ekonomireglementets \$20 kan oanvända medel svarande till maximalt $15 \%$ av årets budget (per budgetpost) överföras till kommande år. Resterande medel beskärs och ska återbetalas till länderna (se även not 4 och 21). 


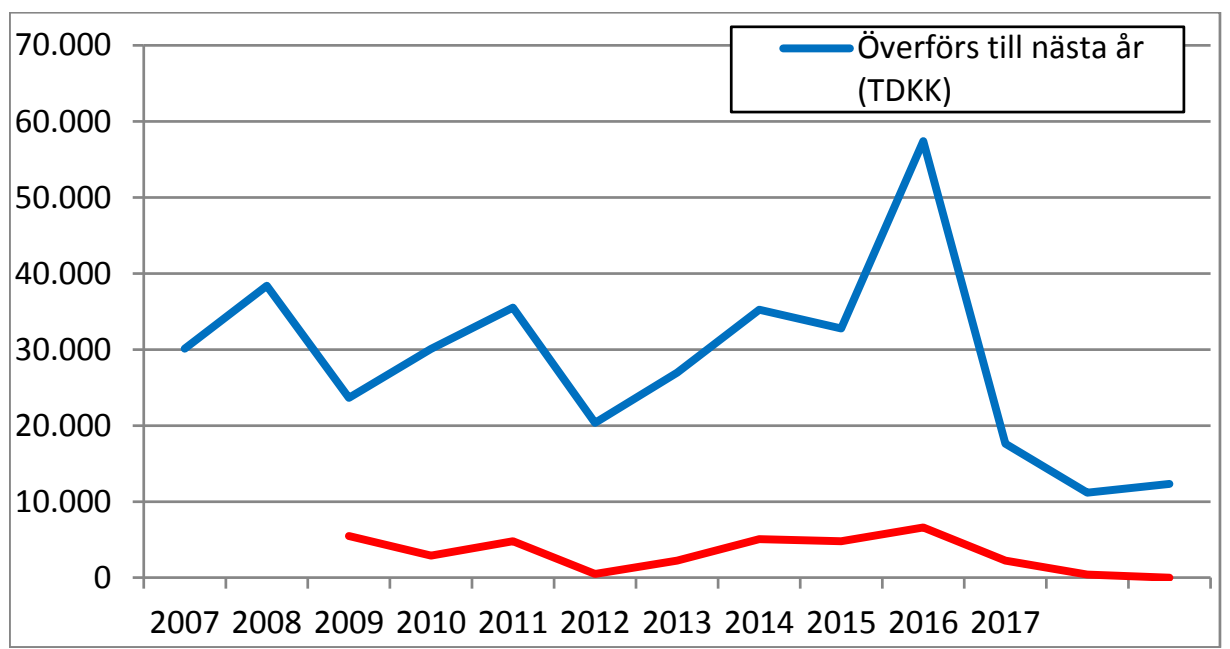

\section{6. Årets resultat}

Årets resultat kan sammanställas enligt följande.

\begin{tabular}{lrrr} 
& 2017 & Budget & Forskel \\
& & & \\
Avgift på lön & 13445 & 13500 & 45 \\
Ränteintäkter och övriga intäkter & 4885 & 0 & 4885 \\
Ränteutgifter och övriga utgifter & -341 & 0 & -341 \\
Övriga intäkter & 0 & 0 & 0 \\
Tillbakabetalda (föråldrade) medel & 5536 & 0 & 5536 \\
\hline Summa & 23535 & 13500 & 10033 \\
Medel beskurna efter 15\%-regeln & & & 422 \\
\hline Årets resultat & & & 10454 \\
\hline
\end{tabular}

Enligt Nordiska ministerrådets ekonomireglemente kan årets resultat betalas tillbaka till länderna om MR-SAM beslutar det i samband med årsrapportens godkännande. En eventuell återbetalning sker utifrån samma fördelningsnyckel som användes vid beräkningen av ländernas bidrag för budgetår 2017.

\section{Likvida medel}

Nordiska ministerrådet hade vid utgången av 2017 totalt 203753 TDKK innestående hos Nordea A/S. Den relativt höga behållningen i slutet av året beror på att ländernas betalning för $\mathrm{O}_{4}$ inbetalas i slutet av året. I starten av 2018 reduceras likviditeten snabbt på grund av stora utbetalningar till institutioner och projekt. Under 2017 har likviditeten 
i DKK under perioder varit under press, vilket har medfört att utbetalningar av projektmedel har fått senareläggas till dess nya inbetalningar gjorts från länderna. För att säkra sekretariatets likviditet under 2017 har drygt 99 MDKK av Nordforsks basbeviljning hållits kvar hos sekretariatet. Likviditetens utveckling har under de senaste åren utvecklats enligt nedanstående graf.

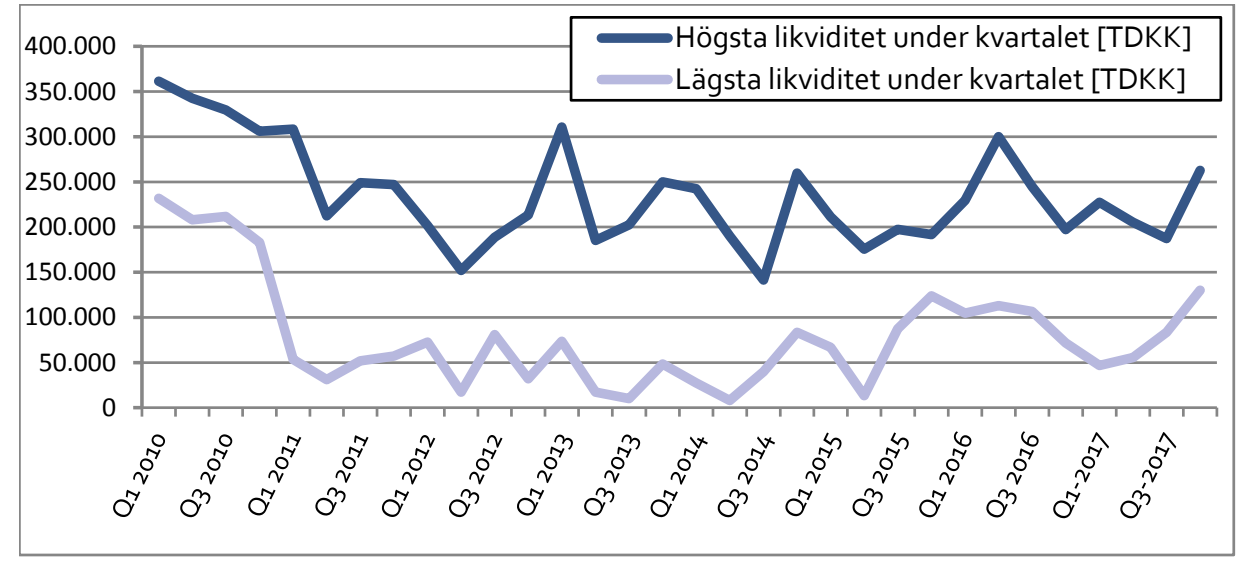

\section{Förskottsbetald lön}

Anställda i Nordiska ministerrådet på nordiska villkor har förskottsbetald lön. Den förutbetalda lönen i balansräkningen motsvarar januarilönen i nästkommande år, och har utbetalts i slutet av december 2017.

\section{9. Övriga fordringar}

Övriga fordringar består primärt av tillgodohavande av moms hos Danska Utrikesministeriet, periodiserade projektutbetalningar samt mellanräkning med Nordiska rådet och Nordiska Kulturfonden.

\section{Periodavgränsningsposter}

Periodavgränsningsposter består av upplupna intäkter, förutbetalda kostnader samt fullmaktsgarantier. Posten består av fullmaktsgaranti för institutionen Nordisk Innovation om 5,5 MDKK (se not 23), övriga förutbetalda kostnader och upplupna kostnader (3,8 MDKK) samt ett belopp som ska avräknas mot återbetalning av årets resultat till länderna (0,7 MDKK). Avräkningen sker mot bakgrund av MR-SAM:s beslut tidigare år om delfinansiering av oförutsedda höga pensionskostnader i den nordiska institutionen NordRegio. 


\section{Eget kapital}

I 2001 beslutade länderna att likviditeten i Nordiska ministerrådet över ett antal år skulle reduceras, och det blev under perioden 2001-2005 tillbakahållet inbetalningar från länderna om totalt 50 MDKK. MR-SAM beslutade 22 maj 2008 att ändra ekonomireglementet så att ministerrådets fordran på länderna avvecklades. I stället framgår den reducerade inbetalningen från länderna som ett negativt egenkapital, och MRSAM beslutade samtidigt att det negativa egenkapitalet skall visas i en not fördelat per land. MR-SAM beslutade vidare att det av noten ska framgå att länderna ansvarar för att det negativa egenkapitalet ska utjämnas genom inbetalning från länderna, när ministerrådets likviditet så kräver.

I samband med budget 2008 blev ytterligare 70 M DKK av årets aktiviteter finansierat genom en reduktion av ministerrådets egenkapital. Det har sedan 2008 inte skett någon reglering av det negativa egenkapitalet, och årliga överskott har i perioden 20082015 tillbakabetalats till länderna. Det samlade egenkapitalet var alltså vid ingången av 2017 -109 801 MDKK, vilket efter tillbakabetalning av resultatet för 2016 om 10199 MDKK reducerats till -120 MDKK. Per 31:e december 2017 utgör det egna kapitalet totalt -109547 MDKK och fördelas mellan länderna enligt följande:

\begin{tabular}{|c|c|c|c|c|c|}
\hline & $\begin{array}{r}\text { Andel av resul- } \\
\text { tat } 2017\end{array}$ & $\begin{array}{r}\text { Tillbakabetalning } \\
\text { ramutvidgning } \\
2017\end{array}$ & $\begin{array}{r}\text { Reduktion av } \\
\text { finansiering } 2008\end{array}$ & $\begin{array}{r}\text { Avskrivet } \\
\text { krav }\end{array}$ & $31 / 122017$ \\
\hline Danmark & 1946 & 96 & -15526 & -11090 & -24574 \\
\hline Finland & 1575 & 75 & -12453 & -8895 & -19698 \\
\hline Island & 80 & 5 & -532 & -380 & -7826 \\
\hline Norge & 3240 & 112 & -20419 & -14585 & -31652 \\
\hline Sverige & 3190 & 134 & -21070 & -15050 & -32797 \\
\hline Summa & 10032 & 422 & -70000 & -50000 & -109547 \\
\hline Saldo per $31 / 122015$ & \multicolumn{4}{|c|}{ Saldo per 31/12 2017} & -109547 \\
\hline
\end{tabular}

Från och med räkenskapsåret 2009 kommer ej disponerade medel som ej kan överföras till efterföljande år betalas tillbaka till länderna tills det att Nordiska ministerrådet har tillbakabetalat 35 MDKK. Medlen betalas till länderna enligt den år 2008 gällande fördelningsnyckeln. Beloppen fördelas mellan länderna enligt följande. 


\begin{tabular}{|c|c|c|c|c|c|c|}
\hline & $\begin{array}{r}\text { Beskuret } \\
\text { (15\% regeln) } \\
2017\end{array}$ & $\begin{array}{r}\text { Beskuret } \\
(15 \% \text { regeln) } \\
2016\end{array}$ & $\begin{array}{r}\text { Beskuret } \\
\text { (15\% regeln) } \\
2015\end{array}$ & $\begin{array}{r}\text { Beskuret } \\
(15 \% \text { regeln) } \\
2014\end{array}$ & $\begin{array}{r}\text { Beskuret } \\
(20 \% \text { regeln) } \\
2009-2013\end{array}$ & $\begin{array}{l}\text { Totalt per } \\
31 / 122017\end{array}$ \\
\hline Danmark & 96 & 508 & 1498 & 1090 & 4302 & 7398 \\
\hline Finland & 75 & 401 & 1181 & 860 & 3393 & 5835 \\
\hline Island & 5 & 29 & 86 & 63 & 246 & 424 \\
\hline Norge & 112 & 596 & 1755 & 1277 & 5041 & 8688 \\
\hline Sverige & 134 & 705 & 2079 & 1510 & 5971 & 10265 \\
\hline Summa & 422 & 2239 & 6599 & 4800 & 18953 & 33011 \\
\hline
\end{tabular}

\section{2. Övriga kortfristiga skulder}

Beloppet består av omkostnader som härrör sig till verksamhetsåret 2017 men där faktura mottagits under 2018.

\section{Fullmaktsgaranti}

Det förekommer i undantagsfall att nordiska institutioner har fullmakt att förpliktiga medel i kommande års budget, och att dessa medel då garanteras av ministerrådet upp till ett maxbelopp (på danska: tilsagnsfuldmagt). Den del av fullmakten som faktiskt har förpliktigats av institutionen tas upp som skuld i ministerrådets balansräkning, och motsvarande belopp tas upp som fordran på länderna som periodavgränsningspost. Vid normal fortsatt drift infrias aldrig varken fullmaktsgaranti eller fordran på länderna. Det är för närvarande institutionen Nordisk Innovation som har en fullmaktsgaranti som uppgår till maximalt 70 MDKK, och nyttjat belopp för 2017 är 5,5 MDKK.

\section{Avsättningar}

Nordiska Ministerrådet har vid flytt från hyrda lokaler en förpliktelse att återställa lokalerna i ursprungligt skick. Kostnader för detta har efter sju års hyra beräknats till 2550 TDKK.

\section{EU-projekt}

Nordiska ministerrådet genomför i samarbete med- och med finansiering från EU följande projekt: 
- Civil Society Stability for Belarus - part two (CSSB)

- Open Europe Scholarship Scheme (OESS)

- European Scholarship Scheme for Young Belarusians (ESSYB)

I tillägg till ovanstående bidrar SIDA till Civil Society Stability for Belarus projekten med totalt 5,9 MSEK.

I januari 2014 beslöts det att flytta administrationen av EU-projekten relaterade till Vitryssland till NMR's kontor i Vilnius (OESS och ESSYB). För ESSYB finns en skuld om 3174 TDKK till NMR kontor i Vilnius upptagen under balansposten Övriga Fordringar.

\section{Projektskuld - NMR-projekt}

Skuld gällande Nordiska ministerrådets projekt kan sammanställas.

\begin{tabular}{lrr} 
& 2017 & 2016 \\
\hline Skuld 1/1 & 278353 & 253277 \\
+ Disponerade medel/projektförpliktelser & 842543 & 820130 \\
- Tillbakaförda medel & -27018 & -30018 \\
- Utbetalda medel & -839150 & -765038 \\
Summa projektskuld 31/12 & $\mathbf{2 5 4 7 2 7}$ & $\mathbf{2 7 8 3 5 0}$ \\
\hline
\end{tabular}

I ovanstående ingår del av basisbeviljning till Nordforsk som innehållits hos NMR på grund av låg likviditet hos NMR och hög likviditet hos Nordforsk under perioden, drygt 99 MDKK.

Nordisk ministerråd har en skuld till Nordregio gällande oförutsedda pensionskostnader till Nodregios direktör enligt ett avtal mellan MR-SAM, EK-R och Nordregio. Beloppet är på 714 TDKK och kommer att regleras i 2018 års utbetalning.

\section{Ytterligare upplysningar}

Nordiska ministerrådet har per 31 december 2010 ingått ett åttaårigt hyreskontrakt gällande lokalerna på Ved Stranden $18 \mathrm{i}$ Köpenhamn. Den samlade förpliktelsen för resterande del av kontraktsbunden hyresperiod är från 31 december 2017 ett år, och uppgår till 6 MDKK. Från 30 juni 2018 är uppsägningstiden 6 månader löpande. 


\section{Bilag 1: Icke disponerade medel}

\begin{tabular}{|c|c|c|c|c|c|c|c|}
\hline & & $\begin{array}{r}\text { Budget } 2017 \\
+\end{array}$ & $\begin{array}{r}\text { Tilbageført i } \\
2017 \\
+\end{array}$ & $\begin{array}{r}\text { Ovf. fra } 2016 \\
+\end{array}$ & $\begin{array}{r}\text { Midler til rå- } \\
\text { dighet } \\
=\end{array}$ & $\begin{array}{r}\text { Anvendt i } \\
2017 \\
-\end{array}$ & $\begin{array}{r}\text { Ikke disp. } \\
\text { midler } \\
+\end{array}$ \\
\hline \multicolumn{2}{|c|}{ MR Samarbejdsministrene } & 258184000 & 18275985 & 4534058 & 280994043 & 274843221 & 6150822 \\
\hline \multicolumn{2}{|c|}{ Prioriteringsbudget } & 91842000 & 10209776 & 2372464 & 104424239 & 100810674 & 3613565 \\
\hline & Projektmidler & 31182000 & 6242300 & 918266 & 38342567 & 37145497 & 1197069 \\
\hline $1-8110$ & Testcenter & 0 & 26197 & 0 & 26197 & 26197 & 0 \\
\hline $1-8112$ & Elmarknaden & o & 21077 & 10465 & 31542 & 31542 & 0 \\
\hline $1-8118$ & Särskilda prioriteringar Grön tillväxt & 0 & 38771 & 0 & 38771 & 38772 & o \\
\hline $1-8410$ & Politiska prioriteringar & 7126000 & 1088740 & 685801 & 8900541 & 8801452 & 99089 \\
\hline $1-8411$ & Politiske initiativer i nærområde & 8593000 & 509980 & 222000 & 9324980 & 8400000 & 924980 \\
\hline $1-8412$ & Till disposition för MR-SAM & 5283000 & 0 & o & 5283000 & 5110000 & 173000 \\
\hline \multirow[t]{2}{*}{$1-8420$} & Profilering og positionering & 10180000 & 4557535 & 0 & 14737535 & 14737535 & 0 \\
\hline & Programlignende aktiviteter & 60660000 & 3967476 & 1454197 & 66081673 & 63665177 & 2416496 \\
\hline $1-8001$ & Nordmin & 0 & 0 & 150000 & 150000 & 150000 & 0 \\
\hline $1-8004$ & Læring på arbeidsplass (LPA) & 0 & 0 & 150000 & 150000 & 150000 & 0 \\
\hline $1-8005$ & Den nordiska spellistan & 0 & 438840 & 64000 & 502840 & 0 & 502840 \\
\hline $1-8007$ & Bioekonomi-initiativet & 0 & 258319 & o & 258319 & 0 & 258319 \\
\hline $1-8008$ & Vækst & 3954000 & 0 & 12000 & 3966000 & 3954000 & 12000 \\
\hline $1-8009$ & Velfærd & 4072000 & o & 128000 & 4200000 & 3702000 & 498000 \\
\hline $1-8010$ & Værdier & 4072000 & 0 & 145000 & 4217000 & 4072000 & 145000 \\
\hline $1-8011$ & Det blå Arktis & 2545000 & 0 & 81000 & 2626000 & 2545000 & 81000 \\
\hline $1-8012$ & $\begin{array}{l}\text { Statistisk utredning över nordisk rörlighet och } \\
\text { förmåner över gränserna }\end{array}$ & 3818000 & 0 & 64000 & 3882000 & 3818000 & 64000 \\
\hline $1-8013$ & $\begin{array}{l}\text { Forskarutbyte mellan de nordiska utrikespoli- } \\
\text { tiska instituten }\end{array}$ & 764000 & o & 17000 & 781000 & 746000 & 35000 \\
\hline $1-8014$ & $\begin{array}{l}\text { Miljömärkning Svanen, cirkulär ekonomi och } \\
\text { miljöavtryck }\end{array}$ & 764000 & o & 13000 & 777000 & 777000 & 0 \\
\hline $1-8015$ & $\begin{array}{l}\text { Ett innovativt och öppet Norden med välmå- } \\
\text { ende människor } 2020\end{array}$ & 2291000 & o & o & 2291000 & 2291000 & o \\
\hline $1-8016$ & Nordisk vägkarta för Blå Bioekonomi & 2291000 & 0 & 38000 & 2329000 & 2291000 & 38000 \\
\hline 1-8017 & $\begin{array}{l}\text { Socio-ekonomisk nytta av arktiska ytvatten i } \\
\text { Norden }\end{array}$ & 1527000 & o & 26000 & 1553000 & 1553000 & o \\
\hline $1-8018$ & The Rising North & 3818000 & 0 & 0 & 3818000 & 3818000 & o \\
\hline $1-8019$ & $\begin{array}{l}\text { Grønn omstilling og konkurransekraft i nor- } \\
\text { diske byregioner }\end{array}$ & 2749000 & o & 0 & 2749000 & 2749000 & o \\
\hline $1-8020$ & Blå og grønn bioøkonomi & 3563000 & 0 & 0 & 3563000 & 3547601 & 15399 \\
\hline $1-8021$ & Helse & 2341000 & o & 0 & 2341000 & 2341000 & 0 \\
\hline $1-8022$ & Integration & 5294000 & 0 & 0 & 5294000 & 5283430 & 10570 \\
\hline $1-8023$ & $\begin{array}{l}\text { Styrket samarbeid mellom de utenrikspoli- } \\
\text { tiske istituttene }\end{array}$ & 509000 & 0 & 0 & 509000 & 484677 & 24323 \\
\hline $1-8024$ & Nordisk energisamarbeid & 814000 & 0 & 0 & 814000 & 814000 & 0 \\
\hline $1-8111$ & $\begin{array}{l}\text { Uddannelse og forskning inden for grøn } \\
\text { vækst }\end{array}$ & 0 & 384886 & 64734 & 449620 & 449620 & o \\
\hline $1-8113$ & $\begin{array}{l}\text { Grønne tekniske normer og standarder - Nor- } \\
\text { den som standardmaker }\end{array}$ & 0 & 29954 & 150000 & 179954 & 179954 & 0 \\
\hline $1-8114$ & Grøn offentlig indkøb & 0 & 16834 & o & 16834 & 16834 & 0 \\
\hline $1-8115$ & $\begin{array}{l}\text { Utveckla tekniker och metoder för avfallshan- } \\
\text { tering }\end{array}$ & 0 & 0 & 418 & 418 & 418 & 0 \\
\hline $1-8210$ & Hållbar nordisk välfärd & 0 & 860165 & 150000 & 1010165 & 1010165 & o \\
\hline $1-8212$ & Välfärd och kost & 0 & 0 & 28000 & 28000 & 28000 & o \\
\hline $1-8510$ & Nye tværgående initiativer & 5294000 & 1978478 & 173045 & 7445524 & 7013478 & 432045 \\
\hline $1-8520$ & $\begin{array}{l}\text { Nordiska lösningar på globala samhällsutma- } \\
\text { ningar }\end{array}$ & 10180000 & 0 & 0 & 10180000 & 9880000 & 300000 \\
\hline
\end{tabular}




\begin{tabular}{|c|c|c|c|c|c|c|c|}
\hline & & $\begin{array}{r}\text { Budget } 2017 \\
+\end{array}$ & $\begin{array}{r}\text { Tilbageført i } \\
2017 \\
+\end{array}$ & $\begin{array}{r}\text { Ovf. fra } 2016 \\
+\end{array}$ & $\begin{array}{r}\text { Midler til rå- } \\
\text { dighet } \\
=\end{array}$ & $\begin{array}{r}\text { Anvendt i } \\
2017 \\
-\end{array}$ & $\begin{array}{r}\text { Ikke disp. } \\
\text { midler } \\
+\end{array}$ \\
\hline \multicolumn{2}{|c|}{ Nordisk Ministerråds fællesaktiviteter } & 31837000 & 4102632 & 1509044 & 37448676 & 35722022 & 1727248 \\
\hline & Projektmidler & 20266000 & 3392776 & 1276591 & 24935368 & 23906987 & 1028974 \\
\hline 1-0435 & Generalsekreterarens disponeringsreserv & 427000 & 9133 & 126099 & 562232 & 562000 & 232 \\
\hline $1-0460$ & Hållbar utveckling & 3132000 & 2687643 & 208483 & 6028126 & 5561134 & 466992 \\
\hline 1-1011 & Informationsaktiviteter & 5345000 & 0 & 395854 & 5740854 & 5275697 & 465157 \\
\hline 1-1012 & Norden I Fokus & 4766000 & 0 & 546156 & 5312156 & 5312156 & 0 \\
\hline \multirow[t]{2}{*}{$1-1030$} & Hallo Norden & 6596000 & 696000 & -1 & 7292000 & 7196000 & 96593 \\
\hline & Programlignende aktiviteter & 7480000 & 709855 & 232453 & 8422308 & 7724035 & 698273 \\
\hline $1-1036$ & Grænsehindringer i Norden & 5061000 & 100740 & 83305 & 5245045 & 4909622 & 335423 \\
\hline $1-1050$ & Tjänstemannautbyte & 1194000 & 609115 & 149148 & 1952263 & 1773163 & 179100 \\
\hline \multirow[t]{2}{*}{$1-2534$} & Bidrag till Nordisk Sommeruniversitet (NSU) & 1225000 & 0 & 0 & 1225000 & 1041250 & 183750 \\
\hline & Organisationsbidrag & 4091000 & $o$ & 0 & 4091000 & 4091000 & 0 \\
\hline $1-0410$ & Föreningarna Nordens Förbund & 3341000 & o & o & 3341000 & 3341000 & 0 \\
\hline $1-0425$ & Bidrag til Grønland & 750000 & o & o & 750000 & 750000 & o \\
\hline \multicolumn{2}{|c|}{ Internationalt samarbejde } & 55261000 & 3955104 & 652551 & 59868655 & 59058051 & 810009 \\
\hline & Projektmidler & 21607000 & 1026582 & 427144 & 23060726 & 23430359 & -370227 \\
\hline $1-0850$ & Internationellt samarbete & 1815000 & 206253 & 132278 & 2153531 & 2832684 & -679747 \\
\hline $1-0870$ & Arktiskt samarbetsprogram & 9024000 & 391099 & 117799 & 9532898 & 9359793 & 173105 \\
\hline $1-0910$ & Politiske initiativer & 0 & 0 & 23888 & 23888 & 23888 & o \\
\hline $1-0960$ & NGO-verksamhet i Östersjöregionen & 6548000 & 388054 & 153026 & 7089081 & 6953999 & 135082 \\
\hline $1-0980$ & Partnerskap och gränsregionalt samarbete & 2562000 & 26306 & 152 & 2588458 & 2587283 & 1175 \\
\hline \multirow[t]{2}{*}{$1-0990$} & Samarbetet med Nordens grannar i Väst & 1658000 & 14870 & 0 & 1672870 & 1672711 & 159 \\
\hline & Programlignende aktiviteter & 17876000 & 2481472 & 180574 & 20538046 & 19814083 & 723963 \\
\hline $1-0820$ & Kunskapsuppbyggning och nätverk & 17876000 & 1714176 & 180574 & 19770750 & 19046787 & 723963 \\
\hline \multirow[t]{2}{*}{$1-0950$} & Hvideruslandsaktiviteter & 0 & 767296 & 0 & 767296 & 767296 & o \\
\hline & Institutioner & 15778000 & 447050 & 44833 & 16269883 & 15813610 & 456273 \\
\hline $1-0810$ & $\begin{array}{l}\text { MR-kontorer i Estland, Letland, Litauen og } \\
\text { Nordvestrusland. }\end{array}$ & 15778000 & 447050 & 44833 & 16269883 & 15813610 & 456273 \\
\hline \multicolumn{2}{|c|}{ Globaliseringsinitiativer } & o & 8473 & o & 8473 & 8473 & o \\
\hline & Projektmidler & 0 & 8473 & 0 & 8473 & 8473 & 0 \\
\hline $1-2020$ & Globaliseringsforum/Grøn Vækst & o & 8473 & o & 8473 & 8473 & o \\
\hline \multicolumn{2}{|c|}{ Aktiviteter med selvstendigt regnskab } & 79244000 & o & o & 79244000 & 79244000 & o \\
\hline & lalt & 79244000 & 0 & 0 & 79244000 & 79244000 & 0 \\
\hline $1-0180$ & Ministerrådets sekretariat (NMRS) & 79244000 & o & o & 79244000 & 79244000 & o \\
\hline \multicolumn{2}{|c|}{ MR-U, MR-S, MR-A } & 274990000 & 5323191 & 1754479 & 282067671 & 280133088 & 1934583 \\
\hline \multicolumn{2}{|l|}{ MR-U } & 221541000 & 2125031 & 1418850 & 225084881 & 224092307 & 992575 \\
\hline & Ministerrådets sekretariat (NMRS) & 11075000 & 2025060 & 948292 & 14048351 & 13665819 & 382532 \\
\hline $2-2505$ & Dispositionsmidler Utbildning och forskning & 3376000 & 1675060 & 367849 & 5418908 & 5036376 & 382532 \\
\hline $2-2544$ & De nordiske sprogsamarbejde & 7123000 & 0 & 580443 & 7703443 & 7703443 & o \\
\hline \multirow[t]{2}{*}{$2-2553$} & $\begin{array}{l}\text { Politikudvikling, Videnssamfund og IT-infra- } \\
\text { struktur }\end{array}$ & 576000 & 350000 & 0 & 926000 & 926000 & 0 \\
\hline & Programlignende aktiviteter & 111024000 & 99971 & 470559 & 111594530 & 110984487 & 610043 \\
\hline $2-2513$ & Nordplus & 74809000 & 99971 & 380559 & 75289530 & 74809000 & 480530 \\
\hline $2-2515$ & Nordic Master Programme & 5497000 & 0 & 90000 & 5587000 & 5457487 & 129513 \\
\hline $2-3127$ & Politikudvikling voksnes læring & 8019000 & 0 & 0 & 8019000 & 8019000 & o \\
\hline $2-3180$ & Nordisk Instut for Teoretisk Fysik (NORDITA) & 9320000 & o & o & 9320000 & 9320000 & o \\
\hline $2-3181$ & Nordiska Instutt for sjørett (NIfS) & 2778000 & o & o & 2778000 & 2778000 & o \\
\hline $2-3182$ & Nordisk Institut for Asienstudier (NIAS) & 4403000 & o & o & 4403000 & 4403000 & o \\
\hline $2-3184$ & Nordisk vulkanologisk institut (NORDVULK) & 4498000 & o & o & 4498000 & 4498000 & o \\
\hline \multirow[t]{2}{*}{$2-3185$} & Nordisk Samisk Institut (NSI) & 1700000 & o & o & 1700000 & 1700000 & o \\
\hline & Institutioner & 99442000 & 0 & $o$ & 99442000 & 99442000 & 0 \\
\hline $2-3100$ & NordForsk & 99442000 & 0 & o & 99442000 & 99442000 & 0 \\
\hline
\end{tabular}




\begin{tabular}{|c|c|c|c|c|c|c|c|}
\hline & & $\begin{array}{l}\text { Budget } 2017 \\
+\end{array}$ & $\begin{array}{l}\text { Tilbageført i } \\
2017 \\
+\end{array}$ & $\begin{array}{l}\text { Ovf. fra } 2016 \\
+\end{array}$ & $\begin{array}{l}\text { Midler til rå- } \\
\text { dighet } \\
=\end{array}$ & $\begin{array}{l}\text { Anvendt i } \\
2017 \\
-\end{array}$ & $\begin{array}{l}\text { lkke disp. } \\
\text { midler } \\
+\end{array}$ \\
\hline \multirow[t]{2}{*}{ MR-S } & & 39363000 & 2458192 & 185468 & 42006660 & 41394334 & 612326 \\
\hline & Projektmidler & 10157000 & 2458192 & 179783 & 12794975 & 12188334 & 606641 \\
\hline $3-4310$ & Projekmedel - Social- och hälsovårdspolitik & 5748000 & 1981037 & 172783 & 7901819 & 7467295 & 434524 \\
\hline $3-4311$ & $\begin{array}{l}\text { Nordisk helsesamarbejde - opfølgning af Bo } \\
\text { Könbergs rapport }\end{array}$ & 1287000 & 477155 & 7000 & 1771155 & 1599039 & 172117 \\
\hline $3-4320$ & $\begin{array}{l}\text { Rådet for nordiskt samarbete om funktions- } \\
\text { hinder }\end{array}$ & 1163000 & 0 & o & 1163000 & 1163000 & 0 \\
\hline \multirow[t]{2}{*}{$3-4340$} & Nomesko og Nososko & 1959000 & 0 & 0 & 1959000 & 1959000 & 0 \\
\hline & Programlignende aktiviteter & 9123000 & 0 & 5685 & 9128685 & 9123000 & 5685 \\
\hline \multirow[t]{2}{*}{$3-4382$} & $\begin{array}{l}\text { NIOM A/S - Nordisk Institutt for Odontolo- } \\
\text { giske Materialer }\end{array}$ & 9123000 & o & 5685 & 9128685 & 9123000 & 5685 \\
\hline & Institutioner & 20083000 & 0 & 0 & 20083000 & 20083000 & 0 \\
\hline $3-4380$ & Nordens Välfärdscenter (NVC) & 20083000 & o & o & 20083000 & 20083000 & 0 \\
\hline \multirow[t]{2}{*}{ MR-A } & & 14086000 & 739969 & 150161 & 14976130 & 14646447 & 329683 \\
\hline & Projektmidler & 2733000 & 47234 & 150000 & 2930234 & 2715809 & 214426 \\
\hline $9-4110$ & Projektmedel i övrigt-Arbetsliv & 1064000 & 47234 & 150000 & 1261234 & 1121894 & 139340 \\
\hline \multirow[t]{2}{*}{$9-4130$} & Kommunikation om arbetsliv & 1669000 & 0 & 0 & 1669000 & 1593914 & 75086 \\
\hline & Programlignende aktiviteter & 7892000 & 692734 & -1 & 8584734 & 8469639 & 115095 \\
\hline $9-4111$ & Arbetslivs fasta utskott & 4620000 & 692734 & -1 & 5312734 & 5197639 & 115095 \\
\hline \multirow[t]{2}{*}{$9-4120$} & Nordjobb & 3272000 & 0 & 0 & 3272000 & 3272000 & 0 \\
\hline & Institutioner & 3461000 & 0 & 162 & 3461162 & 3461000 & 162 \\
\hline $9-4180$ & $\begin{array}{l}\text { Nordiska Institutionen för Vidareutbildning } \\
\text { inom Arbetsmiljöområdet (NIVA) }\end{array}$ & 3461000 & o & 162 & 3461162 & 3461000 & 162 \\
\hline \multicolumn{2}{|c|}{ MR-Kultur, MR-Ligestilling, MR-FJL } & 223817000 & 1914584 & 2909527 & 228641111 & 225362857 & 3278254 \\
\hline \multicolumn{2}{|c|}{ MR-Kultur } & 174413000 & 1189697 & 2452845 & 178055542 & 175378145 & 2677397 \\
\hline & Projektmidler & 11660000 & 1083660 & 1415923 & 14159583 & 12614390 & 1545193 \\
\hline $4-2203$ & Dispostionsmidler Kultur & 974000 & 0 & 125130 & 1099130 & 1091890 & 7240 \\
\hline \multirow[t]{2}{*}{ 4-2208 } & Strategiska satsningar & 10686000 & 1083660 & 1290793 & 13060453 & 11522500 & 1537953 \\
\hline & Programlignende aktiviteter & 106755000 & 106037 & 934290 & 107795326 & 107070755 & 724571 \\
\hline 4-2205 & Nordisk kulturfond & 35555000 & -14526 & 14526 & 35555000 & 35555000 & 0 \\
\hline 4-2206 & Nordisk Råds priser & 4281000 & 22588 & 50450 & 4354038 & 4347040 & 6998 \\
\hline 4-2212 & $\begin{array}{l}\text { Nordisk Børne- og Ungdomskomité (NORD- } \\
\text { BRUK) }\end{array}$ & 6250000 & 97974 & 407107 & 6755082 & 6655887 & 99195 \\
\hline 4-2222 & Nordisk Film- och TV-fond & 28849000 & 0 & 433268 & 29282268 & 28692859 & 589409 \\
\hline $4-2251$ & Kultur- og Kunstprogrammet & 16813000 & 0 & 4995 & 16817995 & 16813000 & 4995 \\
\hline 4-2253 & Nordisk oversættelsesstøtte & 3175000 & 0 & 0 & 3175000 & 3175000 & 0 \\
\hline \multirow[t]{2}{*}{$4-2254$} & $\begin{array}{l}\text { Nordiskt-baltiskt mobilitetsprogram för Kul- } \\
\text { tur }\end{array}$ & 11832000 & 0 & 23945 & 11855945 & 11831970 & 23975 \\
\hline & Institutioner & 46010000 & 0 & 0 & 46010000 & 46010000 & 0 \\
\hline $4-2270$ & Nordens hus i Reykjavik & 11148000 & 0 & o & 11148000 & 11148000 & 0 \\
\hline $4-2272$ & Nordens hus på Färöarna & 13884000 & 0 & o & 13884000 & 13884000 & 0 \\
\hline $4-2274$ & Nordens Institut på Åland & 3023000 & 0 & o & 3023000 & 3023000 & 0 \\
\hline $4-2277$ & Nordens Institut på Grönland & 6507000 & o & o & 6507000 & 6507000 & 0 \\
\hline \multirow[t]{2}{*}{$4-2548$} & Kulturkontakt Nord & 11448000 & 0 & 0 & 11448000 & 11448000 & o \\
\hline & Organisationsbidrag & 9988000 & 0 & 102633 & 10090633 & 9683000 & 407633 \\
\hline $4-2228$ & NORDICOM & 2997000 & o & 0 & 2997000 & 2997000 & 0 \\
\hline $4-2232$ & Prioriterade verksamheter & 3100000 & 0 & 783 & 3100783 & 2795000 & 305783 \\
\hline 4-2234 & Samisk samarbete & 3891000 & o & 101850 & 3992850 & 3891000 & 101850 \\
\hline
\end{tabular}




\begin{tabular}{|c|c|c|c|c|c|c|c|}
\hline & & $\begin{array}{l}\text { Budget } 2017 \\
+\end{array}$ & $\begin{array}{l}\text { Tilbageført i } \\
2017 \\
+\end{array}$ & $\begin{array}{l}\text { Ovf. fra } 2016 \\
+\end{array}$ & $\begin{array}{l}\text { Midler til rå- } \\
\text { dighet } \\
=\end{array}$ & $\begin{array}{l}\text { Anvendt i } \\
2017 \\
-\end{array}$ & $\begin{array}{l}\text { lkke disp. } \\
\text { midler } \\
+\end{array}$ \\
\hline \multirow[t]{2}{*}{ MR-FJLS } & & 40219000 & 91709 & 366512 & 40677221 & 40256712 & 420509 \\
\hline & Projektmidler & 12905000 & 91709 & 366513 & 13363221 & 12942712 & 420510 \\
\hline $5-6310$ & Projektmidler Skovbrug & 317000 & 12623 & 68694 & 398317 & 372886 & 25431 \\
\hline $5-6510$ & Projektmidler Jordbrug & 382000 & 0 & 54250 & 436250 & 409380 & 26870 \\
\hline $5-6610$ & Projektmedel - Fiskeri & 6416000 & 0 & 161799 & 6577799 & 6523423 & 54376 \\
\hline $5-6810$ & Projektmidler - levnedsmidler & 5224000 & 79086 & 56015 & 5359101 & 5071022 & 288079 \\
\hline \multirow[t]{2}{*}{$5-6830$} & $\begin{array}{l}\text { Nordisk Handlingsplan for beddre helse og } \\
\text { livskvalitet }\end{array}$ & 566000 & 0 & 25754 & 591754 & 566000 & 25754 \\
\hline & Programlignende aktiviteter & 7545000 & 0 & -1 & 7545000 & 7545000 & -1 \\
\hline $5-6420$ & Ny nordisk Mad & 939000 & 0 & -1 & 939000 & 939000 & -1 \\
\hline $5-6520$ & Kontaktorgan för jordbrugsforskning & 848000 & o & 0 & 848000 & 848000 & 0 \\
\hline \multirow[t]{2}{*}{$5-6581$} & Samnordisk skogsforskning (SNS) & 5758000 & o & 0 & 5758000 & 5758000 & o \\
\hline & Institutioner & 19769000 & 0 & 0 & 19769000 & 19769000 & 0 \\
\hline $5-6585$ & Nordisk Genressource Center (NordGen) & 19769000 & o & o & 19769000 & 19769000 & o \\
\hline \multicolumn{2}{|c|}{ MR-Ligestilling } & 9185000 & 633179 & 90169 & 9908348 & 9728000 & 180348 \\
\hline & Projektmidler & 6558000 & 633179 & 90169 & 7281348 & 7101000 & 180348 \\
\hline $6-4410$ & Projektmedel - Jämställdhet & 3616000 & 633179 & 90169 & 4339348 & 4159000 & 180348 \\
\hline \multirow[t]{2}{*}{$6-4420$} & MR-JÄMs stödordning & 2942000 & 0 & 0 & 2942000 & 2942000 & 0 \\
\hline & Programlignende aktiviteter & 2627000 & 0 & 0 & 2627000 & 2627000 & 0 \\
\hline $6-4480$ & $\begin{array}{l}\text { Nordisk information för kunskap om kön } \\
\text { (NIKK) }\end{array}$ & 2627000 & o & 0 & 2627000 & 2627000 & 0 \\
\hline \multicolumn{2}{|c|}{ MR-NER, MR-Miljø, MR-Finans } & 176670000 & 1465909 & 1773008 & 179908918 & 178941806 & 967112 \\
\hline \multicolumn{2}{|c|}{ MR-Ner } & 129080000 & 985190 & 1032869 & 131098059 & 130810258 & 287801 \\
\hline & Projektmidler & 11839000 & 771365 & 383379 & 12993744 & 12705943 & 287801 \\
\hline $7-5140$ & Projektmedel Näring & 2056000 & 117259 & 48789 & 2222047 & 2077665 & 144383 \\
\hline $7-5141$ & Projektmedel Energi & 4276000 & 654106 & 48629 & 4978736 & 4843490 & 135246 \\
\hline \multirow[t]{2}{*}{$7-5143$} & $\begin{array}{l}\text { Implementering av samarbetsprogram, de- } \\
\text { mografi, arbetsgrupper och projektmedel }\end{array}$ & 5507000 & 0 & 285961 & 5792961 & 5784789 & 8173 \\
\hline & Programlignende aktiviteter & 25313000 & 213825 & 649490 & 26176315 & 26176315 & 0 \\
\hline $7-5160$ & Gränsregionalt samarbete & 9615000 & 213825 & 649490 & 10478315 & 10478315 & o \\
\hline \multirow[t]{2}{*}{$7-5280$} & Nopef & 15698000 & 0 & 0 & 15698000 & 15698000 & 0 \\
\hline & Institutioner & 85070000 & 0 & 0 & 85070000 & 85070000 & 0 \\
\hline $7-3220$ & Nordisk Energiforskning (NEF) & 6046000 & o & 0 & 6046000 & 6046000 & 0 \\
\hline $7-5180$ & Nordisk Innovation & 67910000 & 0 & 0 & 67910000 & 67910000 & 0 \\
\hline \multirow[t]{2}{*}{$7-6180$} & Nordregio & 11114000 & 0 & 0 & 11114000 & 11114000 & 0 \\
\hline & Organisationsbidrag & 6858000 & 0 & 0 & 6858000 & 6858000 & 0 \\
\hline $7-5151$ & NORA & 6858000 & 0 & 0 & 6858000 & 6858000 & 0 \\
\hline \multirow[t]{2}{*}{ MR-Miljø } & & 45716000 & 399452 & 698667 & 46814119 & 46299823 & 514296 \\
\hline & Projektmidler & 4686000 & 399452 & 646950 & 5732402 & 5680821 & 51581 \\
\hline \multirow[t]{2}{*}{$8-3310$} & Dispositionsmedel - Miljö & 4686000 & 399452 & 646950 & 5732402 & 5680821 & 51581 \\
\hline & Programlignende aktiviteter & 36683000 & 0 & 51717 & 36734717 & 36272002 & 462715 \\
\hline 8-3311 & Miljøsektorens arbejdsgrupper & 24443000 & o & 21717 & 24464717 & 24011002 & 453715 \\
\hline $8-3312$ & Nordisk Råds miljøpris & 835000 & o & 9000 & 844000 & 835000 & 9000 \\
\hline \multirow[t]{2}{*}{$8-3320$} & NEFCOS Miljøudviklingsfond & 11405000 & 0 & 21000 & 11426000 & 11426000 & o \\
\hline & Organisationsbidrag & 4347000 & 0 & $o$ & 4347000 & 4347000 & 0 \\
\hline $8-6720$ & SVANEN-Nordisk miljömärkning & 4347000 & o & 0 & 4347000 & 4347000 & 0 \\
\hline \multicolumn{2}{|c|}{ MR-Finans } & 1874000 & 81268 & 41472 & 1996739 & 1831724 & 165015 \\
\hline & Projektmidler & 1874000 & 81268 & 41472 & 1996739 & 1831724 & 165015 \\
\hline $10-5210$ & Ekonomi- och Finanspolitik & 1874000 & 81268 & 41472 & 1996739 & 1831724 & 165015 \\
\hline \multirow{2}{*}{ MR-Lov } & & 1430000 & 38810 & 210750 & 1679560 & 1669612 & 9948 \\
\hline & Projektmidler & 1430000 & 38810 & 210750 & 1679560 & 1669612 & 9948 \\
\hline $11-7110$ & Projektmedel - Lagstiftning & 1430000 & 38810 & 210750 & 1679560 & 1669612 & 9948 \\
\hline Total & & 935091000 & 27018480 & 11181823 & 973291303 & 960950584 & 12340719 \\
\hline
\end{tabular}




\section{Bilaga 2: Institutionernas ekonomi 2017}

\begin{tabular}{|c|c|c|c|c|c|}
\hline Institution & $\begin{array}{r}\text { Intäkter från } \\
\text { Nordiska Mi- } \\
\text { nisterrådets } \\
\text { Budget }\end{array}$ & $\begin{array}{r}\text { Projekt-bevilj- } \\
\text { ningar från Nor- } \\
\text { diska Ministerrå- } \\
\text { det }\end{array}$ & $\begin{array}{r}\text { Nationella be- } \\
\text { viljningar, Inter- } \\
\text { nationella org. } \\
\text { m.m. }\end{array}$ & Andra intäkter & Totala intäkter \\
\hline \multicolumn{6}{|l|}{ Intäkter (T DKK) } \\
\hline NKK & 11448 & 1870 & 857 & 119 & 14294 \\
\hline NAPA & 6507 & 700 & 4613 & 628 & 12448 \\
\hline NEF & 6046 & 3768 & 27418 & 785 & 38017 \\
\hline $\mathrm{NLH}$ & 13884 & 827 & 1980 & 4584 & 21275 \\
\hline NIPÅ & 3023 & 0 & 750 & 25 & 3799 \\
\hline NIVA & 3461 & 0 & 0 & 2240 & 5701 \\
\hline NordForsk & 99172 & 9862 & 145028 & 4530 & 258593 \\
\hline NordGen & 19953 & 3036 & 6524 & 116 & 29629 \\
\hline Nordisk Innovation & 67910 & 5692 & 4767 & 5247 & 83616 \\
\hline NordRegio & 11114 & 8713 & 2674 & 11299 & 33800 \\
\hline NOREY & 11148 & 5378 & 0 & 1564 & 18090 \\
\hline NVC & 20083 & 11595 & 2809 & 2860 & 37347 \\
\hline
\end{tabular}

\begin{tabular}{|c|c|c|c|c|}
\hline Institution & $\begin{array}{r}\text { Administrativa om- } \\
\text { kostnader }\end{array}$ & $\begin{array}{r}\text { Verksamhets-om- } \\
\text { rådet }\end{array}$ & $\begin{array}{r}\text { Projekt-omkostna- } \\
\text { der }\end{array}$ & Totala utgifter \\
\hline \multicolumn{5}{|l|}{ Utgifter (T DKK) } \\
\hline NKK & 2153 & 10817 & 1132 & 14103 \\
\hline NAPA & 1710 & 10109 & 680 & 12499 \\
\hline NEF & 4386 & 1898 & 31732 & 38016 \\
\hline $\mathrm{NLH}$ & 2922 & 4787 & 12784 & 20493 \\
\hline NIPÅ & 1349 & 2483 & 0 & 3832 \\
\hline NIVA & 1078 & 4305 & 25 & 5407 \\
\hline NordForsk & 4067 & 34085 & 238418 & 276570 \\
\hline NordGen & 3734 & 22709 & 3425 & 29868 \\
\hline Nordisk Innovation & 4157 & 15531 & 59714 & 79403 \\
\hline NordRegio & 4863 & 26881 & 3924 & 35668 \\
\hline NOREY & 3336 & 11156 & 3574 & 18066 \\
\hline NVC & 5671 & 12179 & 19980 & 37830 \\
\hline
\end{tabular}




\begin{tabular}{|c|c|c|c|}
\hline Institution & Likvida medel & Årets resultat & Eget kapital \\
\hline \multicolumn{4}{|c|}{ Övriga nyckeltal (T DKK) } \\
\hline NKK & 4157 & 191 & 3807 \\
\hline NAPA & 1373 & -51 & 650 \\
\hline NEF & 40394 & 1 & 3317 \\
\hline $\mathrm{NLH}$ & 5909 & 782 & 4274 \\
\hline NIPÅ & 742 & -34 & 422 \\
\hline NIVA & 2035 & 294 & 1531 \\
\hline NordForsk & 262228 & -17978 & 3539 \\
\hline NordGen & 15335 & -239 & 5031 \\
\hline Nordisk Innovation & 109039 & 4213 & 8786 \\
\hline NordRegio & 10874 & -1868 & 4968 \\
\hline NOREY & 1865 & 24 & 1178 \\
\hline NVC & 16126 & -483 & 7945 \\
\hline
\end{tabular}




\section{Bilaga 3: Riksrevisionens granskningsrapport - Revision af årsregnskabet for 2017}

Beretning til Nordisk Råd og Nordisk Ministerråd om revisionen af Nordisk Ministerråds virksomhed for 2017

\subsection{Indledning}

Rigsrevisionen afgiver hermed revisionsberetning for regnskabsåret 2017 til Nordisk Råd og Nordisk Ministerråd.

Beretningen har i udkast været fremsendt til Nordisk Ministerråds sekretariat og de øvrige nordiske rigsrevisioner, hvis bemærkninger i videst muligt omfang er indarbejdet.

Beretningen omfatter hele Nordisk Ministerråds årsregnskab for 2017.

Revisionen af Nordisk Ministerråds institutioner, støtteordninger, projekter mv. varetages af de enkelte landes statslige revisionsmyndigheder på grundlag af de gældende bestemmelser i domicillandet.

Vi har fra de øvrige nordiske landes statslige revisionsmyndigheder modtaget rapporteringer om resultatet af årets revision af institutioner, enkeltprojekter mv. Et sammendrag af rapporteringerne er indarbejdet i beretningen, jf. kap. VI.

Årsregnskabet, der behandles på Nordisk Råds ordinære session i efteråret 2018, udviser et overskud på 10,4 mio. kr. og en negativ egenkapital på 109,5 mio. kr. Samarbejdsministrene (MR-SAM) træffer i 2018 beslutning om disponering af årets resultat.

\subsubsection{Konklusion på den udførte revision}

Det er vores opfattelse, at årsregnskabet giver et retvisende billede af Nordisk Ministerråds aktiver, passiver og finansielle stilling pr. 31. december 2017 samt af resultatet af aktiviteterne for regnskabsåret 1. januar - 31. december 2017, og at der er etableret forretningsgange og interne kontroller, der understøtter, at de dispositioner, der er omfattet af årsregnskabet, er i overensstemmelse med love og andre forskrifter samt med indgåede aftaler og sædvanlig praksis.

Det er vores overordnede vurdering, at forvaltningen i 2017 på de områder, vi har undersøgt, er varetaget på en økonomisk hensigtsmæssig måde.

Særlige forhold og kommentarer til årsregnskabet fremgår af kap. II og III. 
Godkender Nordisk Ministerråd årsregnskabet i sin nuværende form, vil årsregnskabet blive forsynet med en revisionspåtegning uden forbehold, men med en supplerende oplysning om, at vi ikke har foretaget revision af budgettal i årsregnskabet.

Vi betragter med vores påtegning revisionen af årsregnskabet for Nordisk Ministerråd for 2017 som afsluttet. Vi kan dog tage spørgsmål vedrørende dette og tidligere regnskabsår op til yderligere undersøgelse. I den forbindelse kan der fremkomme nye oplysninger, som kan give anledning til, at konkrete forhold, der er behandlet ved påtegningen, bliver vurderet på ny.

Revisionens formål, tilrettelæggelse og udførelse fremgår af kap. IV.

\subsection{Særlige forhold vedrørende årsregnskabet for 2017}

\subsubsection{Regnskabspraksis mv.}

Den anvendte regnskabspraksis er vændret i forhold til sidste år. Årsregnskabet for 2017 er aflagt i overensstemmelse med regnskabsbestemmelserne i Nordisk Ministerråds økonomireglement og Nordisk Ministerråds udarbejdede forskrifter.

De enkelte nordiske institutioner aflægger selvstændige årsregnskaber for 2017 efter samme regnskabsprincip, som gælder for Nordisk Ministerråd, dog i enkelte tilfælde modificeret i forhold til nationale regnskabsbestemmelser. For eksempel er det godkendt af Nordisk Ministerråd, at der for Nordisk Institut for Odontologiske Materialer og Nordisk Film- og Tv fond, anvendes den norske "lov om årsregnskap m.v." og god regnskapsskik i Norge, som regnskabsprincipper.

\subsubsection{Samarbejdsaftaler $m v$.}

Nordisk Ministerråds sekretariat har i lighed med tidligere år haft samarbejdsaftaler med henholdsvis Nordisk Råds sekretariat og Nordisk Kulturfonds sekretariat om bl.a. forvaltning af løn- og økonomifunktionen, som Nordisk Ministerråds sekretariat mod betaling stiller til rådighed for de 2 øvrige sekretariater.

I forbindelse med vores gennemgang af samarbejdsaftalerne med de 2 sekretariater har vi konstateret, at aftalerne for 2017 er opdateret og fornyet i november 2016.

\subsection{Kommentarer til årsregnskabet}

På grundlag af vores revision finder vi, at de etablerede forretningsgange og interne kontroller ved regnskabsførelsen og regnskabsaflæggelsen understøtter regnskabets rigtighed, og at årsregnskabet giver et retvisende billede af Nordisk Ministerråds aktiver, passiver og finansielle stilling pr. 31. december 2017, samt af resultatet af Nordisk Ministerråds aktiviteter for regnskabsåret 1. januar - 31. december 2017. 


\subsubsection{Den samlede resultatopgørelse}

Nordisk Ministerråds resultat for 2017 viser et overskud på 10,5 mio. kr. mod et overskud på 10,2 mio. kr. i 2016. Den mindre stigning i overskuddet skyldes blandt andet, en stigning i bidrag fra landene, fra 2016 til 2017 på 6,9 mio. kr., modsat dog en stigning i omkostninger til ministerrådets sekretariat på 6,5 mio. kr.

I henhold til Nordisk Ministerråds økonomireglement kan årets overskud tilbagebetales til landene, såfremt samarbejdsministrene (MR-SAM) i forbindelse med regnskabets endelige vedtagelse tager beslutning herom. En eventuel tilbagebetaling sker ud fra den samme fordelingsnøgle, der blev anvendt ved fastlæggelsen af landenes bidrag for budgetåret 2017.

De samlede indtægter udgør 945,9 mio. kr. i 2017 mod 938,1 mio. kr. i 2016, hvoraf bidragene fra de nordiske lande udgør hovedparten.

Vi har konstateret, at der i 2017 ikke har været renteindtægter, derimod har der i årets løb været negative renter på indestående på likvidkontoen på o,4 mio. kr.

Indtægtsposten "Øvrige indtægter" udgør 4,9 mio. kr. i 2017 mod 1,9 mio. kr. i 2016. Denne har været påvirket positivt af en valutakursgevinst ved betaling af gæld til Nordforsk i norske kroner (NOK), i forhold til den omregnede kurs på balancedagen.

De samlede omkostninger, ekskl. tilbageførte midler, udgør 966 mio. kr. i 2017 mod 964 mio. kr. i 2016. Heraf anvendes 882 mio. kr. til institutioner, samarbejdsorganer, enkeltprojekter og kontorer i Baltikum og Rusland, mens 84,4 mio. kr. anvendes til driften af sekretariatet.

Tilbageførte midler (ej forældede) er midler fra aktiviteter, som enten har været afholdt til lavere omkostninger end budgetteret eller aktiviteter som ikke er gennemført, og som ikke er faldet for 3 årsreglen, der fastlægger at tilsagn fra Nordisk Ministerråd kan overføres til det følgende budgetår og længst til det derpå følgende budgetår. Midlerne anvendes i løbet af året til finansiering af Nordisk Ministerråds aktiviteter. Posten viser et fald fra 30,0 mio. kr. i 2016 til 27,0 mio. kr. i 2017.

\subsubsection{Nordisk Ministerråds sekretariat}

Vi har for personaleomkostningerne gennemgået afstemningen mellem lønsystemet, der anvendes i Nordisk Ministerråd, og bogføringen og påset, at der er overensstemmelse mellem lønsystemet og bogføringen. Herudover har vi stikprøvevist kontrolleret at lønsedler stemmer til kontrakterne. 


\subsubsection{Den samlede balance}

De likvide midler på 204 mio. kr. udgør hovedparten (91 \%) af de samlede aktiver på 223 mio. kr. pr. 31. december 2017. De likvide midler er steget med 17 mio. kr. i forhold til ultimo 2016.

Under fordringerne er der indregnet forudbetalt løn mv. på 3,6 mio. kr. og øvrige fordringer inkl. momsrefusion på 5,8 mio. kr.

Vi har stikprøvevist påset, at øvrige fordringer løbende indfries.

Overførte midler udgør i 2017 i alt 32,9 mio. kr. mod 36,6 mio. kr. i 2016. Af de overførte midler i 2017 udgør de ikke-disponerede midler 12,3 mio. kr., hvilket er udtryk for den del af budgetmidlerne, der ikke er disponeret til specifikke formål ved årets udgang.

Vi skal i lighed med tidligere år henlede opmærksomheden på, at den kortfristede gæld pr. 31. december 2017 overstiger omsætningsaktiverne med 76,6 mio. kr.

Generelt bør omsætningsaktiverne være af en sådan størrelse, at det er muligt at indfri den kortfristede gæld. Al projektgæld indgår imidlertid som kortfristet gæld, selv om projekterne kan løbe over flere år, og dermed normalvis kategoriseres som langfristet gæld.

Nordisk Ministerråds økonomiafdeling har tidligere oplyst, at det ikke er muligt at foretage en meningsfyldt opdeling af projektgælden, da en opdeling vil forudsætte entydige betalingsplaner for de enkelte projekter, hvilket imidlertid ikke er muligt, da projekternes fremdrift generelt afviger fra de oprindelige planer. Nordisk Ministerråds økonomiafdeling har derfor valgt at undlade en opdeling af projektgælden, indtil der er etableret en brugbar måde at foretage opdelingen på.

Nordisk Ministerråd har hertil tidligere oplyst, at dette skal ses i sammenhæng med den negative egenkapital.

I forbindelse med Nordisk Ministerråds implementering af nyt økonomisystem i år finder vi, at der er en god anledning til at styrke regnskabsføringen på dette område således, at det bliver muligt at opdele projektgælden mere præcist år for år.

Nordisk Ministerråds egenkapital udgør -109,5 mio. kr. ultimo 2017. Egenkapitalen udgør det afskrevne krav på indbetalingerne fra landene i 2005 på -50 mio. kr., underbudgetteringen i 2008 med -70 mio. kr. og de efterfølgende årlige reguleringer som følge af årets resultat og eventuelle tilbagebetalinger til landene.

I 2017 blev der tilbagebetalt 20,6 mio. kr. til landene, dette udgøres af årets resultat og tilbagebetaling af ubrugt ramme for 2016.

Ifølge Nordisk Ministerråds Økonomireglement vil den negative egenkapital på MR-SAM's foranledning blive udlignet gennem indbetalinger fra landene, når likviditeten betinger dette. 


\subsection{Den udførte revision}

\subsubsection{Revisionens formål, tilrettelæggelse og udførelse}

Formålet med vores revision af årsregnskabet er at påse, at ledelsens aflagte regnskab er udarbejdet i overensstemmelse med Nordisk Ministerråds økonomireglement og Nordisk Ministerråds udarbejdede forskrifter, og at årsregnskabet giver et retvisende billede af Nordisk Ministerråds aktiver, passiver og finansielle stilling samt resultat.

Revisionen har hovedsageligt omfattet regnskabsposter og områder, hvor der er risiko for væsentlige fejl og mangler, jf. pkt. 23.

Forekommer der tilsigtede fejl og mangler, vil der være risiko for, at disse forbliver uopdagede. Det er Nordisk Ministerråds ansvar at tilrettelægge hensigtsmæssige registreringssystemer, forretningsgange og interne kontroller for at forebygge og opdage såvel tilsigtede som utilsigtede fejl og mangler samt at påse, at disse foranstaltninger overholdes.

Revisionen udvides, hvis der under revisionen konstateres forhold, som vækker mistanke om uregelmæssigheder. Revisionen har ikke givet anledning til en sådan udvidelse.

\subsubsection{Risikofyldte områder}

Vores strategi for tilrettelæggelsen af revisionen er fastlagt med henblik på at fokusere på områder, hvor der er risiko for væsentlige fejl og mangler.

De væsentlige og risikofyldte områder har været:

- Nordisk Ministerråds interne kontroller, der omfatter de overordnede kontroller, inklusiv tilskudsforvaltningen, og kontroller på de regnskabsmæssige områder.

- Den generelle administration af tilskudsforvaltningen, særligt opfølgningen på regnskabsaflæggelsen for de ydede tilskud.

- Tilbageførte projektmidler.

- Løn-og personaleområdet.

- Fordringer, periodeafgrænsningsposter, skyldige projektomkostninger og kreditorer.

- Anskaffelse af inventar og udstyr, samt indkøb af andre tjenesteydelser.

\subsubsection{Revisionens udførelse}

Revisionen har omfattet en gennemgang af forretningsgangene $\mathrm{i}$ forbindelse med regnskabsudarbejdelsen og en stikprøvevis gennemgang af dokumentationen for de oplysninger og beløbsangivelser, der er anført i årsregnskabet. Vi har påset, at de gældsposter og øvrige forpligtelser, der os bekendt påhviler Nordisk Ministerråd, er kommet rigtigt til udtryk i årsregnskabet. 
Den finansielle revision har også omfattet en vurdering af, om der er etableret forretningsgange og interne kontroller, der understøtter, at de dispositioner, der er omfattet af årsregnskabet, er i overensstemmelse med love og andre forskrifter samt med indgåede aftaler og sædvanlig praksis. Herudover har vi stikprøvevist påset, at der er taget skyldige økonomiske hensyn ved de dispositioner, der er omfattet af årsregnskabet.

\subsubsection{Revision af skyldige økonomiske hensyn}

Ved den gennemførte revision har vi udført forvaltningsrevision. Formålet med revisionen har jævnfør revisionsreglementets $\$ 4$ været at foretage en vurdering af, om der for udvalgte områder, er taget skyldige økonomiske hensyn ved forvaltningen af Nordisk Ministerråd.

Vi har ved stikprøver gennemgået administrationsudgifterne for at påse, at der er taget skyldige økonomiske hensyn ved forvaltningen af Nordisk Ministerråds midler. Ved revisionen gennemgik vi herunder de væsentligste poster for indkøb i Nordisk Ministerråd.

Ved bilagsgennemgangen ved den afsluttende revision har vi ikke stødt på bilag der gav anledning til yderligere undersøgelse af sparsommeligheden ved disponeringen af disse.

\subsubsection{Revision af styring af tilskudsordninger}

Vi har desuden udført forvaltningsrevision med det formål, at undersøge at der ikke forekommer væsentlige, uopdagede forvaltningsmangler ved Nordisk Ministerråds styring af offentlige nordiske tilskudsordninger og herunder at vurdere, om de undersøgte systemer, processer og dispositioner understøtter en effektiv forvaltning.

Vi har undersøgt om Nordisk Ministerråd har klare rammer for tilskudsordningerne, herunder om rammerne sikrer, at midlerne bruges efter hensigten. Herefter har vi undersøgt om Nordisk Ministerråd følger op på tilskudsordningerne, herunder på om tilskudsordningerne fungerer efter hensigten.

Vores revision har vist, at Nordisk Ministerråd har fastlagt klare rammer for tilskudsordningerne og at Nordisk Ministerråd følger op på tilskudsordningerne.

\subsubsection{Revision af afgørelser om tildeling af tilskud}

I den gennemførte revision har vi endelig udført juridisk kritisk revision af Nordisk Ministerråds afgørelser om tildeling af tilskud. Formålet har været at undersøge om der for afgørelser om tildeling af tilskud ikke har forekommet væsentlige uopdagede regelbrud. Vi har på den baggrund undersøgt, om Nordisk Ministerråds tildeling af tilskud varetages i overensstemmelse med de relevante kriterier, der følger af gældende ret, og om de lever op til kravene i de relevante retsnormer. 
Vi har undersøgt, om Nordisk Ministerråds forretningsgange og interne kontroller ved tildeling af tilskud eller anden finansiering understøtter, at tilskuddet tildeles i overensstemmelse med love, bekendtgørelser, vedtægter og andre relevante retsnormer. Vi har derefter ved gennemgang af stikprøver undersøgt, om Nordisk Ministerråd følger forretningsgangene og de interne kontroller og dermed lever op til kravene i de relevante retsnormer.

Det er vores vurdering, at Nordisk Ministerråds rammer for forvaltning af tilskud har relevant hjemmel i retsnormer, herunder budgetbogen (Nordisk Ministerråd Planer og budget 2017). Vi vurderer ligeledes, at Nordisk Ministerråds forretningsgange og interne kontroller sikrer, at tilskud tildeles i overensstemmelse med hjemlen. Der er ved Nordisk Ministerråds forvaltning af tilskud en høj grad af politisk- og embedsmands involvering fra medlemslandene, og der føres systematisk dokumentation med beslutninger om tildeling af tilskud i de enkelte sektorers ministerråd, embedsmandskomiteer, arbejdsgrupper og lignende.

Vores revision er baseret på gennemgang af seks tilskud på tre forskellige sektorer, og vi vurderer at disse var tildelt i overensstemmelse med den relevante hjemmel og de relevante kriterier.

\subsection{Nordisk Ministerråds kontorer}

Vi har i 2017 fravalgt at udføre løbende revision hos Nordisk Ministerråds informationskontorer i Baltikum. I den afsluttende revision har vi gennemgået informationskontorernes regnskaber, og udtaget enkelte stikprøver herfra, samt foretaget regnskabsanalytiske handlinger af væsentlige udsving. Gennemgangen viste at der var forklaringer på udsving i relevant omfang og de udtagne stikprøver gav ikke anledning til yderligere revisionshandlinger.

\subsection{Revision af Nordisk Ministerråds institutioner, enkeltprojek- ter mv.}

\subsubsection{Generelt}

Ansvaret for revisionen af regnskaber for institutioner, der er beliggende i Norden, er placeret hos den statslige revisionsmyndighed i institutionens domicilland. Efter aftale med vedkommende rigsrevision kan revisionen dog varetages af et autoriseret/offentlig godkendt revisionsfirma.

Enkeltprojekter mv. revideres som hovedregel stikprøvevist af de enkelte landes rigsrevisioner som led i revisionen af regnskaberne for de pågældende institutioner eller forvaltningsorganer, hvortil projektet er knyttet. For projekter, støtteordninger mv., der ikke er henlagt til statslige institutioner, varetages revisionen af privat revisionsfirmaer. Vi reviderer de projekter, der administreres af Nordisk Ministerråds sekretariat. 
Vi videresendte den 21. februar 2018 en oversigt fra Nordisk Ministerråds sekretariat over projekter for 2017, der var fordelt på de enkelte lande, til de nordiske rigsrevisioner til brug for deres projektrevisioner.

\subsubsection{Nordisk Ministerråds institutioner}

Ved afslutning af revisionen af en institutions årsregnskab afgives en revisionspåtegning, der efter behov kan suppleres med en revisionsrapport. Der kan være forskelle i hvor detaljerede de enkelte afrapporteringer er, hvorfor bemærkningerne vedrørende revisionen af udvalgte institutioner i pkt. 40-49 nedenfor, ikke nødvendigvis er et udtryk for omfanget af fejl i de enkelte nordiske landes institutioner.

Der er 3 fællesnordiske institutioner i Finland, der alle revideres af private revisionsfirmaer.

Der er afgivet revisionspåtegning uden forbehold eller supplerende oplysninger for dem alle for regnskabsåret 2017.

Nordens Hus i Island revideres af Ríkisendurskoðun.

Der er afgivet revisionspåtegning uden forbehold eller supplerende oplysninger for institutionen for regnskabsåret 2017, men bemærker i sin revisionsrapport, at der er manglende funktionsadskillelse, blandt andet for funktionen for lønberegning, indtægter og fakturering.

Riksrevisjonen varetager revisionen af 4 af de 5 nordiske institutioner og organer, der er beliggende i Norge. Den 5 . institution revideres af et privat revisionsfirma.

Der er afgivet revisionspåtegninger uden forbehold eller supplerende oplysninger for alle 5 institutioner og organer.

Riksrevisjonen har i år afgivet udtalelse om øvrige forhold for NordForsk. Denne er afgivet med en moderat grad af sikkerhed og er baseret ISSAI 4000 (compliance audit). Det er her undersøgt om institutionernes disponering af bevillingerne i væsentlig grad er i strid med de norske administrative regler for økonomistyring. Riksrevisjonen konkluderede at dette ikke var tilfældet.

De 3 nordiske institutioner, der er beliggende i Sverige, revideres af Riksrevisionen.

Riksrevisionen har for alle 3 institutioner afgivet revisionspåtegninger uden forbehold eller supplerende oplysninger.

Selvstyreområderne Grønland og Åland har hver én nordisk institution. Hvor Færøerne har to nordiske institutioner. Institutionen på Grønland revideres af et privat revisionsfirma, ligesom institutionerne på Færøerne. Ålands Landskapsrevisionen varetager revisionen af Nordens institut på Åland.

Der er afgivet revisionspåtegning uden forbehold eller supplerende oplysninger for institutionerne på Færøerne og Åland, mens der er afgivet en supplerende oplysning for institutionen på Grønland om, at regnskabets indeholdte budgettal ikke er revideret.

Bemærkninger vedrørende revisionen af udvalgte institutioner mv. 


\subsubsection{Nordregio, Sverige}

Riksrevisionen har i år gennemgået Nordregio's fakturahåndtering og personale omkostninger, og disse viste ikke nogen afvigelser.

Riksrevisionen har konstateret, at der i årsrapporten er fejlagtige oplysninger på side $20 \mathrm{~g} 26$, hvor det angives at personaleomkostningerne overstiger budgettet med 2,2 mio. SEK. og at omkostninger til køb af varer og tjenesteydelser overstiger budgettet med 1,9 mio. SEK. Som det fremgår ved sammenligning mellem resultat og budget i resultatopgørelsen, er de korrekte beløb henholdsvis 2,9 mio. SEK. og 1,3 mio. SEK.

Riksrevisionen konstaterede herudover, at oplysningerne i årsrapportens side 4 indeholder visse mindre fejlagtigheder omkring antallet af mål. Det totale antal mål burde være 80 i stedet for de angivne 81, og antallet af opfyldte mål burde være $68 \mathrm{i}$ stedet for de angivne 71. Antallet af delvist opnåede mål burde være 8 i stedet for 10 . Dette medfører at den procentuelle målopfyldelse, som angives til $87,65 \%$, i stedet burde være $85 \%$ (68/80).

\subsubsection{Nordens Genresurscenter (NordGen), Sverige}

Riksrevisionen har i år gennemgået NordGen's fakturahåndtering og personale omkostninger, og disse viste ikke nogen afvigelser.

Riksrevisionen har fulgt op på NordGens videreformidling af bidrag vedrørende PPP-projektet (Public Private Partnership for prebreeding in plants). Opfølgningen viste, at NordGen i princippet havde udbedret alle de mangler som Riksrevisionen tidligere har fundet. Dog blev det bemærket, at NordGen stadig bør dokumentere sine interne retningslinjer tydeligere på dette område, hvilket NordGen efterfølgende har påbegyndt arbejdet med.

For årsrapporten har Riksrevisionen konstateret, at NordGen i 2017 har ændret regnskabsprincip for hvilken typer af omkostninger der indregnes under posterne "Varer og tjenesteydelser" og "Øvrige omkostninger" i resultatopgørelsen. Hertil bemærkes, at man for at muliggøre meningsfuld sammenligning år for år for disse poster, burde have omregnet sammenligningstallet for 2016. Hvis dette ikke har været praktisk muligt, burde man i stedet have oplyst om ændringen i årsrapporten og forklaret at sammenligningstallene ikke er omregnede.

\subsubsection{Nordens Välfärdscenter (NVC), Sverige}

Riksrevisionen har i år gennemgået NVC's fakturahåndtering og personale omkostninger, og disse viste ikke nogen afvigelser.

Riksrevisionen har konstateret, at to bidragsudbetalinger til sammenlagt 1.054 TSEK er bogført som omkostninger for tjenesteydelser. Dette skyldes at bidragene adskiller sig fra NVCs normale bidrag, og man var derfor usikker på hvad disse skulle klassificeres. Riksrevisionen vurderer at bidragene skulle have været regnskabsført under posten "Bidrag til eksterne projekter", og vurderer samtidigt at dette er en klassificeringsfejl uden resultatpåvirkning. 
Riksrevisionen har konstateret, at der i årsrapporten var fejlagtige periodiseringer for sammenlagt ca. 133 TSEK. Dette medførte, at omkostningerne der vedrører regnskabsåret 2017 fejlagtigt har belastet 2018.

Riksrevisionen har desuden anbefalet NVC, at indføre procedurer om dualitet ved udbetalinger fra NVCs finske bankkonto i Danske Bank, i lighed med de tilsvarende procedurer for de svenske bankkonti.

\subsection{Andre oplysninger mv.}

\subsubsection{Lejemålet "Ved Stranden 18"}

Nordisk Ministerråd har indgået en otteårig lejeaftale vedrørende lokalerne på "Ved Stranden 18 ", og den resterende del af lejeperioden er 1 år. Det oplyses i årsrapportens note 27 , at den samlede forpligtelse hertil udgør 6 mio. kr.

Vi har tidligere haft en dialog med Nordisk Ministerråd om deres forpligtelse til at reetablere lejemålet ved fraflytning, Nordisk Ministerråd hensatte i 2017 2,6 mio. kr. til reetableringen, hvilket fremgår af note 24 .

\subsubsection{Eftersyn af Nordisk Ministerråds protokoller}

Vi har påset, at der føres protokol for afholdte møder i Nordisk Ministerråd (MR-SAM og Nordisk Samarbejdskomité (NSK)), og at beslutninger vedtaget på møderne afspejles i årsregnskabet. Vi har læst protokollerne for møder afholdt i 2017.

\subsubsection{Overholdelse af lovgivningen}

Den daglige ledelse har skriftligt erklæret, at der ledelsen bekendt ikke har været aktuelle eller mulige overtrædelser af lovgivningen, hvis konsekvenser skal overvejes i forbindelse med udarbejdelse af årsregnskabet.

Vi er i forbindelse med vores revision:

- Ikke blevet bekendt med forhold, der indikerer eller vækker mistanke om, at der i Nordisk Ministerråd udøves aktiviteter, der strider imod lovgivningen.

- Ikke blevet bekendt med forhold, der indikerer, at medlemmerne af ledelsen eller NSK/ MR-SAM for Nordisk Ministerråd kan ifalde erstatnings- og/eller strafansvar.

- Ikke blevet bekendt med overtrædelse af bogføringsloven i Nordisk Ministerråd.

\subsubsection{Risiko for besvigelser af væsentlig betydning for årsregnskabet}

Vi har med Nordisk Ministerråds ledelse drøftet risikoen for væsentlig fejlinformation i årsregnskabet som følge af besvigelser eller fejl. Formålet med drøftelserne er at opnå 
en forståelse af ledelsens vurdering, dels af risikoen for, at årsregnskabet kan indeholde væsentlig fejlinformation som følge af besvigelser og fejl, dels af kontrolforanstaltninger til forebyggelse heraf.

Ledelsen har over for os bekræftet sit ansvar for udformning, implementering og vedligeholdelse af regnskabs- og kontrolsystemer med henblik på at forebygge og opdage besvigelser og fejl, og at den ikke har kendskab til eller formodning om besvigelser og fejl af betydning for årsregnskabet.

Vi er i forbindelse med vores revision heller ikke blevet bekendt med forhold, der indikerer eller vækker mistanke om, at der i Nordisk Ministerråd er foregået besvigelser.

\subsubsection{Ledelsens regnskabserklæring}

Vi har indhentet en regnskabserklæring fra generalsekretæren og den økonomiansvarlige i Nordisk Ministerråds sekretariat.

Den skriftlige erklæring er tilfredsstillende og omfatter årsregnskabets fuldstændighed og andre områder, hvor det er vanskeligt at opnå revisionsbevis.

\subsubsection{Ikke-korrigerede forhold}

Vi skal som led i revisionen oplyse MR-SAM om, hvorvidt der er forhold, som ikke er korrigeret i årsregnskabet, fordi den daglige ledelse har vurderet, at de er uvæsentlige både enkeltvist og sammenlagt for årsregnskabet som helhed.

Denne oplysning skal gives for at sikre, at MR-SAM er orienteret om og kan tilslutte sig den af den daglige ledelse foretagne vurdering.

Der er ingen ikke-korrigerede forhold i det foreliggende årsregnskab.

\subsubsection{Afsluttende bemærkninger}

I henhold til \21 i Nordisk Ministerråds økonomireglement skal vi erklære at have modtaget alle de oplysninger, der er anmodet om under revisionen.

København, den 11. juni 2018

Lone Strøm

Henrik Lange 
Nordiska ministerrådet

Nordens Hus

Ved Stranden 18

DK-1061 København K

www.norden.org 